\title{
Cancer Biomarker Profiling Using Nanozyme Containing Iron Oxide Loaded with Gold Particles
}

Victor Akpe ${ }^{* 1,2}$, Muhammad J.A. Shiddiky*1,3, Tak H. Kim ${ }^{1,2}$, Christopher L.Brown ${ }^{1,2}$, Yusuke Yamauchi $^{4}, \operatorname{lan}$ E. Cock*1,2

\section{Affiliations}

1 School of Environment and Science, Griffith University, Nathan Campus, QLD 4111, Australia.

2 Environmental Futures Research Institute, Griffith University, Nathan Campus, QLD 4111, Australia.

3 Queensland Micro and Nanotechnology Centre, Griffith University, Nathan, Queensland 4111, Australia, Griffith University, Nathan Campus, QLD 4111, Australia.

4 School of Chemical Engineering and Australian Institute for Bioengineering and Nanotechnology (AIBN), University of Queensland, Brisbane, QLD 4072, Australia.

* Corresponding Author

Email: $\underline{\text { I.Cock@griffith.edu.au }}$

Conflict-of-interest: All authors declare no conflict of interest 


\section{Abstract}

Nanozymes are nanomaterials with intrinsic magnetism and superparamagnetic properties. In the presence of an external magnet, nanozyme particles aggregate and redisperse without a foreign attraction. We evaluated the performances of nanozyme by changing the biosensing platforms and substituting other biological variants for a complete cancer assay detection. We investigated the expression of morphological variants in the transmission of signals using an electrochemical method. The signal responses, including signal enhancement with the nanozyme ( $\mathrm{Au}-\mathrm{Fe}_{2} \mathrm{O}_{3}$ ), showed a wide capturing range ( $>80 \%$, from $10^{2}-10^{5}$ cells / $\mathrm{mL}$ in PBS buffer, $\mathrm{pH}$ 7.4). The platform showed a fast response time within a dynamic range of $10-10^{5}$ cells / $\mathrm{mL}$ for the investigated T47D cancer cell line. We also obtained higher responses for anti-HER2 (Human Epidermal Receptor 2)/streptavidin interface as the biosensing electrode in the presence of T47D cancer cells. The positive assay produced a 6-fold increase in current output compared to the negative target or negative biological variant. We calculated the limit of detection, $\mathrm{LOD}$ at $0.4 \mathrm{U} / \mathrm{mL}$, and quantitation, $\mathrm{LOQ}$ at $4 \mathrm{U} / \mathrm{mL}$ (units per milliliter). However, blood volume amounts in clinical settings may constrain diagnosis and increase detection limit value significantly.

Keywords: Amperometry Detection, Cancer Biomarkers, Limit of Detection, Biosensor Amplification,

\section{Introduction}

Cancer biomarkers are increasingly relevant in diagnostic, prognostic, and therapeutic evaluations of patient survival and long-term clinical management. Biomarkers are biological tools use for mapping the metastatic cascade in vitro and in vivo environments. More recently, interest in cancer-based interface technologies is expanding the detection of earlystage disease [1]. However, cancer cells are highly heterogeneous, and the quantitative profiling of biomarkers using analytical methods of detection becomes imperative.

Some of the standard techniques for profiling biomarkers include electrochemical, fluorescence, surface-enhanced Raman scattering (SERS), and surface plasmon resonance (SPR) techniques. Importantly, electrochemical applications to biological environments using biomolecule-nanomaterials at the electrode interface may play a lead role in point-of-care settings (POC) in the future [2]. The integration of nanomaterials to biosensing platforms also 
may display enzyme mimic properties [3]. Nano-based platforms can facilitate cancer cells capture and release [4], charge transfer reactions [5], enhance the signal read out at the electrode surface [6]. These attributes make nano-based sensing platforms extremely sensitive, significant, over complementary techniques [7].

Iron oxide nanomaterials display enzyme-mimic properties towards chromogenic substances [8]. It is a common knowledge that nanoparticles can replace the enzyme, horseradish peroxidase (HRP) during the oxidation of tetramethylbenzidine (TMB) $[9,10]$. The oxide nanomaterials are beneficial as capture agents and catalysts in the detection of autoantibodies and microRNA biological samples [11-14]. Thus, materials with nanoscale dimensions, especially with porous architecture, electrical, and optical properties, are significant in biomedical applications $[13,15,16]$.

Not only are electrochemical tools essential for profiling the redox status of a biological or chemical environment, the technique is the gold standard for redox enzymes on thin-film electrode surfaces. Currently, third-generation biosensors involving the integration of porous gold or platinum particles are in demand for high market potential, superior sensitivity, and nanoporous-mimicking activities for signal amplification $[17,18]$. We describe in this paper the strategies and evaluation of cancer biomarkers with iron oxide loaded with Au particles (nanozyme), conjugated with antibodies raised against specific biomarkers.

\subsection{Biomarker expression levels in breast cancer cells}

Biomarkers are cell surface receptors expressed by healthy or cancer cells. However, cancer cells overexpress biological molecules produced at the cell surface. The way to measure the expression is by matching the biomarker to a specific antibody (bioreceptor) it recognises. Depending on the interaction, the signal transduction can either be low or high and is distinct to one cell type. The concept around modification is, therefore, enhancing the signal output using any of the standard techniques. We provide a summary of the cancer biomarkers (scheme 1). T47D cell line was used as the breast cancer cell model and OVCAR3 (ovarian cell line) as the control experiment. 


\section{Experimental}

\subsection{Material and methods}

The synthesis and characterisation of $\mathrm{Au}^{-} \mathrm{Fe}_{2} \mathrm{O}_{3}$ (nanozyme) $(10 \mathrm{mg}$ ), including the loading/releasing effects have been reported previously [19]. Abcam supplied the biotin (Type B) fast conjugation (ab201796) kit. R \& D systems, Australia, provided the human antibodies for HER-2, PD-L1, EGFR, and EpCAM. We restored the powdered antibodies to the liquid state just before use at the company's recommendation concentration at $0.50 \mathrm{mg} / \mathrm{mL}$, except for EpCAM human antibody supplied as a liquid and reconstituted at $1.00 \mathrm{mg} / \mathrm{mL}$ ). R\&D Systems, Australia, provided CA-125 antibody used as the capturing agent and the biosensing platform for the negative control experiments. Life Technologies, Australia, supplied the phosphate buffer saline (10 mM, pH 7.4)). Invitrogen, Australia provided the bovine serum albumin (BSA, $50 \mathrm{mg} / \mathrm{mL}$ ). The stock solution was diluted to $0.1 \mathrm{wt}$. \% before use as a blocking agent. SigmaAldrich, Australia, supplied polyethylene glycol (PEG-8000). The 1\% PEG solution was used to stabilise antibody molecules during $\mathrm{Au}-\mathrm{Fe}_{2} \mathrm{O}_{3}$ functionalisation. Sigma-Aldrich, Australia, provided the hydroquinone $(\mathrm{HQ})$ that was used to prepare the stock solution $(10 \mathrm{mM})$. Chemsupply, Australia, supplied hydrogen peroxide $\left(\mathrm{H}_{2} \mathrm{O}_{2}, 30\right.$ wt. \%) and potassium ferrocyanide trihydrate (AR grade). The water conductivity provided at $0.025 \mu \mathrm{S} / \mathrm{cm}$. Antibody reconstitution and further dilutions prepared in sterile PBS buffer, except otherwise specified.

Metrohm Dropsens, Spain, supplied all the disposable streptavidin electrodes used on the $\mathrm{CH}$ instrument model 700E series workstation. We preconditioned the electrodes at room temperature for 30 minutes. The samples and assays prepared on Eppendorf Thermomixer at $23^{\circ} \mathrm{C}$ and $300 \mathrm{rpm}$. Thermo Scientific Heraeus ${ }^{\mathrm{TM}} \mathrm{Pico}^{\mathrm{TM}} 17$ microcentrifuge tubes were used for the separation of the unbound EpCAM antibodies. The anti-EpCAM/Au- $\mathrm{Fe}_{2} \mathrm{O}_{3}$ was extracted by discarding the supernatant solution. Thermo Fisher Scientific supplied Countess II used to count the number of free cells and digital images of cancer cells captured. Invitrogen, Australia, supplied the trypan blue $(0.4 \%$, Invitrogen) for the cell staining. Thermo Fischer Scientific, supplied the DynaMag magnetic separation rack used for the washing and isolation of the cells captured.

\subsection{Cell culture preparation}

We used the subculture cells of the human adenocarcinoma breast and ovarian cancer cell lines of the American Type Culture Collection (ATCC).Dulbecco's Modified Eagle Medium 
(DMEM) from Gibco supplied the cell culture nutrient requirements. Thermofisher Scientific supplied the fetal bovine serum (FBS) used for cell growth. Overall, the cell media constituted (90\% DMEM, 5\% FBS plus 0.5\% penicillin-streptomycin). Subculture cells maintained in the incubator at $5 \% \mathrm{CO}_{2}, 37{ }^{\circ} \mathrm{C}$. We harvested the cancer cells at $80 \%$ confluency with TryLE ${ }^{\mathrm{TM}}$ Express and retrieve them as pellets at $2500 \mathrm{rpm}$ for $5 \mathrm{~min}$. The cancer cells dispersed in $1 \mathrm{~mL}$ PBS buffer solution at $\mathrm{pH} 7.4$.

\subsection{EpCAM antibody coating with biotin}

Abcam supplied the biotin kit used for anti-EpCAM coating. We added a $1 \mu \mathrm{L}$ modifier reagent directly to $10 \mu \mathrm{L}$ EpCAM antibody $(10 \mathrm{ng} / \mathrm{mL})$ at room temperature. Then gently mixed biotin powder for another 15 minutes. We stopped the reaction with a quencher reagent $(1 \mu \mathrm{L})$ and used directly without further purification.

\subsection{Cancer cells captured with $\mathrm{Au}-\mathrm{Fe}_{2} \mathrm{O}_{3}$ (nanozyme), Scheme 3(1)}

We modified the preparations according to the papers referenced [20-24]. We gently mixed $20 \mu \mathrm{L}$ nanozyme $(1.0 \mathrm{mg} / \mathrm{mL})$ with $10 \mu \mathrm{L}$ EpCAM antibody $(10 \mathrm{ng} / \mathrm{mL})$ for $5 \mathrm{~min}$ and added $1.0 \mu \mathrm{L}$ of $1.0 \%$ PEG. Then stirred the sample mixture on a thermomixer for $30 \mathrm{~min}$ at room temperature. The centrifuge process removed the unreacted EpCAM antibody, and $\mathrm{Au}-\mathrm{Fe}_{2} \mathrm{O}_{3}$ / EpCAM antibody conjugate dispersed in $20 \mu \mathrm{L}$ PBS buffer solution. The nanozyme-EpCAM antibody conjugate was washed twice and dispersed in $10 \mu \mathrm{L}$ PBS buffer solution containing 1\% PEG $(1.0 \mu \mathrm{L})$. We extracted the aggregate particles with an external magnet and redispersed in $10 \mu \mathrm{L}$ of T47D cells at the required cancer concentration ranges.

\subsection{Cancer cells captured with magnetic beads, MBs, Scheme 3(2)}

We vortexed the streptavidin coated MBs $(10 \mathrm{mg} / \mathrm{mL})$ for $30 \mathrm{~s}$ and transferred $30 \mu \mathrm{L}$ to a 1.5 $\mathrm{mL}$ tube. We mixed $1 \mathrm{mg} / \mathrm{mL}$ (x10 dilution) of streptavidin coated MBs with $10 \mu \mathrm{L}$ of biotin coated EpCAM antibody (10 ng /mL) described in section 2.3. After stirring for $30 \mathrm{~min}$ on a thermomixer, the mixture was washed on a magnetic rack and dispersed in $10 \mu \mathrm{L}$ PBS solution. We extracted the aggregate particles with an external magnet and redispersed in 10 $\mu \mathrm{L}$ of T47D cells at the required cancer concentration range.

\subsection{Cancer cells captured with double-modified nanozyme and magnetic beads, Scheme 3(1)}


The final samples products of schemes 3 (1), nanozyme / anti-EpCAM and 3(2), MBs /antiEpCAM were used to capture T47D cancer cells according to modifications of published methods [11, 22, 23]. We split $10 \mu \mathrm{L}$ of harvested cells dispersed in PBS buffer equally and transferred the preconcentrate of schemes 3(1) and 3(2). We merged the two mixtures and mixed on a thermomixer at $\left(23^{\circ} \mathrm{C}, 300 \mathrm{rpm}\right.$ for one hour). The captured cells were extracted using magnetic separation and redispersed in $10 \mu \mathrm{L}$ PBS buffer solution.

\subsection{Complete assay development}

We developed a biorecognition platform for each assay route following the steps taken in sections 2.4 to 2.6 . First, we added $10 \mu \mathrm{L}$ of biotin coated anti-EpCAM (10 ng/mL) to a streptavidin-modified electrode surface and mixed for one hour at $23{ }^{\circ} \mathrm{C}$ and 300 revolutions per minute (rpm). The streptavidin modified surface was washed twice with a $5 \mu \mathrm{L}$ PBS buffer solution to remove the unreacted biotin coated anti-EpCAM. We blocked the non-specific EpCAM antibody on the electrode surface with 0.1\% BSA. Then, we transferred the cancer cells captured using the descriptions of sections 2.4 to 2.6 according the general schematic routes (figure 1 ).

\subsection{Direct cancer cells capture on the streptavidin-coated electrode surface}

The direct cell capture process follows a modification from a published method [23]. We added a $10 \mu \mathrm{L}$ of biotin coated anti-EpCAM $(10 \mathrm{ng} / \mathrm{mL})$ to a streptavidin-modified electrode surface and mixed for one hour at $23{ }^{\circ} \mathrm{C}$ and 300 revolutions per minute (rpm). The electrode surface was washed twice with a $5 \mu \mathrm{L}$ PBS buffer solution to remove the unreacted biotin coated anti-EpCAM. Subsequently, we blocked the non-specific EpCAM antibody on the electrode surface with $0.1 \%$ BSA concentration for $10 \mathrm{~min}$. Then, we transferred $10 \mu \mathrm{L}$ of T47D cells dispersed in PBS at $\left(10^{5}\right.$ cells $\left./ \mathrm{mL}\right)$. The assay was incubated on the thermomixer for one hour and washed sparingly with (scheme not indicated).

\section{Results and discussion}

We investigated the platforms for cancer cells capture, compared the amperometry performance, and profiled biomarker expression levels using a breast cancer model. T47D cell line was used as the ideal breast cancer model because the cancer cells have more distinctive molecular characteristics than the MCF-7 cell line. MCF-7 is also susceptible to 
progesterone (PR) of the luminal A subtype breast cancer family [25]. Luminal T47D cells also displays tightly cohesive mass structures [26].

In this study, we used T47D cells for the positive experiment and OVCAR-3 for the control experiment (scheme 1). Since EpCAM expression in cancer cells is significantly high [27], we used anti-EpCAM/nanozyme as the dispersible capture agent to recognise T47D cells expression of EpCAM. Additionally, we evaluated the positive HER-2 expression of T47D breast cancer type using an HER-2 antibody. Importantly, HER-2 forms heterodimers easily with EGFR, and T47D breast cancer type is known to display a preponderance of the protein [28]. However, PD-L1 (programmed cell death) receptor in breast cancer types, is associated with large size tumour, estrogen receptor, ER (-), progesterone receptor, PR-, HER-2(+) in HER2 enriched subtype [29]. CA-125 is a significant biomarker in ovarian cancer patients, and $90 \%$ of women with the disease have elevated serum levels [30].

We incorporated nanomaterials as our capture cargo to increase (I) the surface area (ii) provide high surface activity (iii) provide good adsorption capacity (iv) concentrate the analytes and (v) amplify the signal. To this end, we developed the biorecognition platforms by immobilising biotin (Bo.) coated antibodies to streptavidin-modified electrodes (STE). The following modified electrodes were used, STE/Bio. (i) Anti-HER2 (ii) Anti-EGFR (iii) CA-125 antibody and (iv) Anti-PD-L1.

The general preparation route before detection (scheme 2 ) consisted of (I) nanomaterial functionalisation (II) cell capture (III) biorecognition staging and (IV) electrochemical profiling. The inclusion of PEG to the nanomaterials and biomolecules confer stability to the molecular assemblies. PEG can also increase the antibody hydration, thereby enhancing the stability of the conjugate during the PEGylating process $[23,31]$. PEG functionalisation increased the stability of the conjugation (antibody-PEG---nanomaterials).

The biosensing platform involves the formation of non-covalent interactions between biotin and the streptavidin modified electrode surface. The addition of a BSA solution blocks any non-specific protein-surface and protein-protein interactions that may hinder assay performance during use as a biorecognition platform[32, 33]. In this report, we used a $0.1 \%$ BSA concentration solution for $10 \mathrm{~min}$ at room temperature incubation as the optimal blocking condition. While other blocking agents including, Tween 20 [34], PEG [31], milk proteins [35], and serum albumins [36] are equally good, BSA participation as a blocking agent shows the least steric hindrance during protein-protein binding [31]. Adopting this approach 
increased the sensitivity and specificity of our biorecognition platforms. The different pathways initially considered for the comparative performance of the best performing breast cancer assays (scheme 3 ) is in Table 1, with a more elaborate discussion elsewhere (figure 4).

The differential pulse voltammetry (DPV) profile (figure 1) measured the serial dilution of BSA concentrations on the surface of the biorecognition platform. We obtained the layer by layer interface with the stepwise addition of a $2 \mathrm{mM}\left[\mathrm{Fe}(\mathrm{CN})_{6}\right]^{4-/ 3-}$ of an electrolyte solution. The first layer formed the profile of the biorecognition platform after adding a redox probe, $\mathrm{Fe}\left[(\mathrm{CN})_{6}\right]^{3-/ 4-}$, with a successive dilution of BSA concentration (figure $1 \mathrm{a}$ ) and linear range of BSA concentration (figure $1 \mathrm{~b}$ ). The profiling and calibration of the BSA concentration confirmed two things. First that the biosensing platform had a functional signal readout as the drop in current correlated to the increase in BSA concentration (figure 1a). Second, the linear BSA range indicated the acceptable concentration range for use as a blocking agent (figure $1 \mathrm{~b}$ ). We used a $0.1 \%$ BSA in all the experiments to minimise steric hindrance and increase the specificity and sensitivity of the biorecognition platform.

A similar DPV profile for the reactant molecules (figure 2 ) indirectly or directly attached to the surface of the same biorecognition platform showed a current decrease as the biological concomitant moieties increased on the electrode surface. The Faradaic current corresponds to the partial flow of electrons $[37,38]$. As the concentration of biomolecule moieties increased, electrons access to the surface were partially hindered, leading to a drop in the current response. The limitations with the DPV technique are that the sensitivity increases with a small group of reactants and is not suitable for copious reactants or minuscule reactants with no detectable signal[39]. Interestingly, amperometry biosensors depend mostly on the electrode properties, with signal response near to the biosensing electrode[6].

We obtained the amperometry response profile (figure 3 ) by adding $35 \mu \mathrm{L}$ of $1 \mathrm{mM} \mathrm{HQ}$ to the test sample to give a momentary baseline signal. Then followed it with the addition of 35 $\mu \mathrm{L}$ of $10 \mathrm{mM} \mathrm{H}_{2} \mathrm{O}_{2}(30 \% \mathrm{v} / \mathrm{v})$. The encounter of $\mathrm{HQ}$ solution with $\mathrm{H}_{2} \mathrm{O}_{2}$ on the electrode surface leads to a charge transfer of electrons. The electron transfer takes place during the oxidation of $\mathrm{HQ}$ to $\mathrm{Q}$. The lift (or jump) in signal response is at the point of addition of $\mathrm{H}_{2} \mathrm{O}_{2}$. The returned plateau (stabilised signal) is relative to the $\mathrm{HQ}$ response, and the difference is the amperometry response of the assay.

The inclusion of nanomaterials to a biosensor is to amplify the signal and concentrate the analytes for detection. The Amperometry biosensor depends on the current resulting from 
the redox reaction of a biorecognition platform, and it is the source that provides the specific, quantitative analytical information. Nanomaterials inclusion in cancer-based assays tends to produce higher current responses in amperometry technique. Kung et al. [40], showed the oxidation of $H Q$ to $Q$ increased in the presence of Fe oxide derivative as the concentration of hydroquinone decreased. Also, oxides with a higher surface area, oxidise twice as much HQ to quinone and $\mathrm{pH}$ had little or no effect on the oxidation of hydroquinone in the presence of an iron oxide loaded surface material [40]. Unexpectedly, the amperometry profile (figure 4, table 1) indicated a lower response in Scheme 3(3), $\square 40 \mu \mathrm{A}$ than the nanozyme assay in Scheme 3 (1), $\square 100 \mu \mathrm{A}$. There was no signal response in Scheme 3(2) containing MBs, suggesting there was a partial flow of electron from nanozyme in the double-modified nanomaterials in Scheme 3(3). We also suggest, replacing the biosensing interface with Bio.anti-HER2 in Scheme 3(3) may increase the dual-signal amplification performance. The direct capture method with EPCAM immobilised STE, produced a relatively low net signal response $(\square \mu \mathrm{A})$. Nonetheless, Scheme 3(1) pathway with nanozyme produced the highest signal response $(\square 00 \mu \mathrm{A})$.

We calculated the amperometry responses by considering the response without cells (control), response with cells and the net response of the biosensing platform (figure 4) according to the following calculations,

Amperometry response, $A m p_{(R)}=I_{R}\left(H Q / H_{2} \mathrm{O}_{2}\right.$ stabilised response) $-I_{R}(H Q$ addition)

where $\mathrm{I}_{\mathrm{R}}\left(\mathrm{HQ} / \mathrm{H}_{2} \mathrm{O}_{2}\right.$ stabilised response) is the stabilised current response at the addition of $\mathrm{HQ} / \mathrm{H}_{2} \mathrm{O}_{2}$ and $\mathrm{I}_{\mathrm{R}}$ ( $\mathrm{HQ}$ addition is the current response at the addition of $\mathrm{HQ}$ only). Here, we noted that $\mathrm{HQ}$ addition induced different current responses, attributed to the different interface layers. Therefore, subtracting equation 1 removed the solvent background and other interfering signals during the redox process. The net amperometry response, Amperometry response with cells - Amperometry response without cells The net signal response corresponds to the amperometry response of the cancer biomarker profiling.

We showed nanozyme capture efficiency of cancer cells (figures $5 a$ and $5 b$ ) and postcapture sub-culture (figure $5 \mathrm{c}$ ) at different cell concentrations $\left(10^{5}\right.$ to 10 cells $\left./ \mathrm{mL}\right)$. The green colour mapping (figure $5 \mathrm{c}$ ) were the viable cells and the red colour mapping the dead cells. Interestingly, we observed viable cells growth of post capture release after 6 hrs in a tissue 
culture flask (figure $5 \mathrm{c}$ ). The result from Figure 5 showed the practicability of using the nanozyme capture platform in post-capture culture expansions.

The precursor derivative of nanozyme without the gold particles demonstrate great potential as efficient transport and control release of drug. Noteworthy, gold particles loading to iron oxide (nanozyme structure) provides fast adsorption of antigen and antibodies on the gold particles surface. The incubation of cells in either free serum or serum proteins (BSA) may either increase the cellular uptake of the nanoparticles via endocytosis [41] or inhibit the cellular uptake of the nanoparticles using the so-called "scavenger receptors" in serumcontaining samples [42]. The present study considers the cell surface attachment to Au particles $\left(\mathrm{Au}-\mathrm{Fe}_{2} \mathrm{O}_{3}\right)$ as the probable mechanism and not endocytosis.

The calibration plot (figure $6 \mathrm{~b}$ ) was used to calculate the limit of detection, LOD, and the limit of quantitation, $L O Q$ using the direct amperometry response for the serial dilution of T47D cells in the presence of $\mathrm{HQ} / \mathrm{H}_{2} \mathrm{O}_{2}$ (figure 6a). We obtained the LOD and LOQ calculations from a linear regression plot [43]. Then we used the plot as the model to compute the LOD and LOQ as follows,

For a linear plot; $y=a x+b$

$\mathrm{LOD}=3 \mathrm{~S} / \mathrm{a}$

$\mathrm{LOQ}=10 \mathrm{~S} / \mathrm{a}$

$\mathrm{S}$ is the standard deviation of the response (represents the standard error in this report), and a is the slope of the calibration plot within the dynamic range for the serial dilution of cell concentration. Compared to the LOD of the existing biosensor platforms (table 2), we obtained a significantly low (LOD $0.4 \mathrm{UmL}^{-1}$ and LOQ, $4 \mathrm{~mL}^{-1}$ ), with good reproducibility within the linear range of cancer cell detection.

We also investigated the amperometry responses for the positive and negative experiments (figure 7). There was increase in signal response with the biosensing platform as STE/Bio.anti-HER in the presence of T47D cells. However, control assays (negative control) with OVCAR3, no cancer cells, or a negative marker as a capture agent, or as part of a biosensing platform, produced relatively low signal responses, equivalent to approximately one-sixth in the output response of the positive setup assay. Since the immediate signal response of a negative test is not necessarily a zero response [6], the direct amperometry responses for the negative control set up (figure $7 b$ ) were within experimental measurements 
. The negative control can only be zero or insignificant using the net amperometry response calculation in equations 1 and 2 .

We also investigated the mean amperometry responses using different biosensing interfaces (figure 8), biotinylated (I) anti-HER2, (II) anti-EGFR, and (III) anti-PD-L1, to profile biomarker expression levels in T47D cells. The cancer cells captured, T47D-Anti.EpCAM-Au$\mathrm{Fe}_{2} \mathrm{O}_{3}$ remained the same during the amperometry measurement. Interestingly, we observed significant amperometry responses. The biosensing platform with anti-HER 2 responded with the highest signal, suggesting the presence of HER2 (+). The low PD-L1 signal response may suggest unidentified biomarkers of ER (-), PR (-), and high progesterone (PR+) levels. In a similar work conducted by Cahall ([53] using a flow cytometry analysis, the EGFR: HER-2 obtained, 1:2 fold expression detection with the flow cytometry method [53]. We got a 1:55 fold expression detection. The PD-L1 expression, as opposed to EGFR expression, suggests a slight upregulation in the presence of ( $\mathrm{HQ} / \mathrm{BQ}$ system), which may be due to cytotoxic local immune response [29].

\section{Conclusions}

The cancer assay developed using nanozyme and anti-HER2 antibody as the biosensing interface exhibited high sensitivity and low LOD. We obtained a LOD value, $0.4 \mathrm{UmL}^{-1}$, and LOQ, $4 \mathrm{UmL}^{-1}$. Compared to the existing biosensor platforms available, the streptavidinmodified electrode surface reproducibility is significantly high. We also obtained a wide capturing range (> $80 \%$, from $10-10^{5}$ cells / $\mathrm{mL}$ in PBS buffer, $\mathrm{pH} 7.4$ ) for the T47D cancer cells. We showed the practicability of a post-capture expansion of the cancer cells, which may be useful in the evaluation of the phenotypes. The selective responses obtained by changing the biorecognition platform is proof of concept that this platform is suitable for cancer biomarker profiling.

Data accessibility. The authors confirm that the data supporting the findings of this study are available within the results section of this paper.

Authors' contributions. V.A carried out the laboratory work and data analysis, participated in the design of the study, coordinated the study and draft the manuscript; M.J.A.S participated in the design of the study, coordinated the study and helped draft the manuscript; T.H.K coordinated the manuscript and helped draft the manuscript; C.L.B coordinated the manuscript and helped draft the manuscript; Y.Y. provided the nanozyme and the technical information about the material; I.E.C. coordinated the study and helped draft the manuscript. All authors gave final approval for publication.

Competing interests. We have no competing interest. 
Funding. V.A acknowledges research grant from the Griffith University towards doctoral programme. Acknowledgements. V.A acknowledges the Griffith University for the GUPR and GUIPR scholarships.

\section{References}

[1] Jha, N.K., Jha, S.K., Sharma, A., Yadav, R., Pandey, P., Kesari, K.K., Kumar, N., Nand, P., Agrahari, M. \& Gupta, N.S. 2020 Clinical Relevance of "Biomarkers" in Cancer Metabolism. In Cancer Cell Metabolism: A Potential Target for Cancer Therapy (ed. D. Kumar), pp. 127-146. Singapore, Springer Singapore.

[2] Mittal, S. 2017 Biosensors for Breast Cancer Diagnosis: A Review of Bioreceptors, Biotransducers and Signal Amplification Strategies. Biosensors \& Bioelectronics 88, 217-231.

[3] Revathi, C. 2019 Enzymatic and Nonenzymatic Electrochemical Biosensors. In Fundamentals and Sensing Applications of 2D Materials (pp. 259-300, Elsevier.

[4] Yu, X. 2013 Magneto-Controllable Capture and Release of Cancer Cells by Using a Micropillar Device Decorated with Graphite Oxide-Coated Magnetic Nanoparticles. Small (Weinheim an der Bergstrasse, Germany) 9, 3895-3901.

[5] Luo, Y. 2009 Detection of Extracellular H O Released from Human Liver Cancer Cells Based on TiO Nanoneedles with Enhanced Electron Transfer of Cytochrome. Analytical Chemistry (Washington) 81, 3035-3041.

[6] Topkaya, S.N. 2016 Electrochemical Biosensors for Cancer Biomarkers Detection: Recent Advances and Challenges. Electroanalysis (New York, N.Y.) 28, 1402-1419.

[7] Huang, X., O'Connor, R. \& Kwizera, E.A. 2017 Gold Nanoparticle Based Platforms for Circulating Cancer Marker Detection. Nanotheranostics (Sydney, NSW.) 1, 80.

[8] Gao, L. 2017 Iron Oxide Nanozyme: A Multifunctional Enzyme Mimetic for Biomedical Applications. Theranostics 7, 3207-3227.

[9] Bhattacharjee, R., Tanaka, S., Moriam, S., Masud, M.K., Lin, J., Alshehri, S.M., Ahamad, T., Salunkhe, R.R., Nguyen, N.-T. \& Yamauchi, Y. 2018 Porous Nanozymes: The Peroxidase-Mimetic Activity of Mesoporous Iron Oxide for the Colorimetric and Electrochemical Detection of Global DNA Methylation. Journal of Materials Chemistry B.

[10] Yadav, S. 2017 Gold-Loaded Nanoporous Iron Oxide Nanocubes: A Novel Dispersible Capture Agent for Tumor-Associated Autoantibody Analysis in Serum. Nanoscale 9, 8805-8814.

[11] Ambrosi, A. 2007 Double-Codified Gold Nanolabels for Enhanced Immunoanalysis. Analytical Chemistry (Washington) 79, 5232-5240.

[12] Bhattacharjee, R. 2018 Porous Nanozymes: The Peroxidase-Mimetic Activity of Mesoporous Iron Oxide for the Colorimetric and Electrochemical Detection of Global DNA Methylation. Journal of Materials Chemistry. B, Materials for Biology and Medicine 6, 4783-4791.

[13] Islam, M.N. 2017 A PCR-free Electrochemical Method for Messenger RNA Detection in Cancer Tissue Samples. Biosensors \& Bioelectronics 98, 227-233.

[14] Islam, M.N. 2018 Gold-Loaded Nanoporous Ferric Oxide Nanocubes for Electrocatalytic Detection of MicroRNA at Attomolar Level. Biosensors \& Bioelectronics 101, 275-281.

[15] Kaneti, Y.V. 2017 Strategies for Improving the Functionality of Zeolitic Imidazolate Frameworks: Tailoring Nanoarchitectures for Functional Applications. Advanced Materials (Weinheim) 29.

[16] Masud, M.K. 2017 Gold-Loaded Nanoporous Ferric Oxide Nanocubes with Peroxidase-Mimicking Activity for Electrocatalytic and Colorimetric Detection of Autoantibody. Analytical Chemistry (Washington) 89, 11005-11013.

[17] Das, P. 2016 Recent Advances on Developing 3rd Generation Enzyme Electrode for Biosensor Applications. Biosensors \& Bioelectronics 79, 386-397.

[18] Taurino, I. 2016 Recent Advances in Third Generation Biosensors Based on Au and Pt Nanostructured Electrodes. TrAC, Trends in Analytical Chemistry (Regular ed.) 79, 151-159. 
[19] Zakaria, M.B. 2015 Prussian Blue Derived Nanoporous Iron Oxides as Anticancer Drug Carriers for Magnetic-Guided Chemotherapy. Chemistry, an Asian Journal 10.

[20] Ambrosi. 2007 Double-Codified Gold Nanolabels for Enhanced Immunoanalysis. Analytical Chemistry (Washington) 79.

[21] Boriachek, K. 2019 Avoiding Pre-Isolation Step in Exosome Analysis: Direct Isolation and Sensitive Detection of Exosomes Using Gold-Loaded Nanoporous Ferric Oxide Nanozymes. Analytical Chemistry (Washington) 91, 3827-3834.

[22] Maltez-Da, C. 2012 Simple Monitoring of Cancer Cells Using Nanoparticles. Nano Letters 12.

[23] Min, H. 2015 Efficient Capture and Simple Quantification of Circulating Tumor Cells Using Quantum Dots and Magnetic Beads. Small (Weinheim an der Bergstrasse, Germany) 11, 2536-2542.

[24] Perfézou, M. 2012 Cancer Detection Using Nanoparticle-Based Sensors. Chemical Society Reviews 41, 2606-2622.

[25] Yu, S. 2017 The T47D Cell Line is an Ideal Experimental Model to Elucidate the ProgesteroneSpecific Effects of a Luminal A subtype of Breast Cancer. Biochemical and Biophysical Research Communications 486, 752-758.

[26] Holliday, D.L. 2011 Choosing the Right Cell Line for Breast Cancer Research. Breast Cancer Research : $B C R 13$.

[27] Königsberg, R. 2011 Detection of EpCAM Positive and Negative Circulating Tumor Cells in Metastatic Breast Cancer Patients. Acta Oncologica 50, 700-710.

[28] Eccles, S.A. 2001 The Role of c-erbB-2/HER2/neu in Breast Cancer Progression and Metastasis. Journal of Mammary Gland Biology and Neoplasia 6.

[29] Sabatier, R. 2015 Prognostic and Predictive Value of PDL1 Expression in Breast Cancer. Oncotarget 6.

[30] Razmi, N. 2018 Current Advancement on Diagnosis of Ovarian Cancer Using Biosensing of CA 125 Biomarker: Analytical Approaches. TrAC, Trends in Analytical Chemistry (Regular ed.) 108, 1-12.

[31] Reimhult. 2008 QCM-D Analysis of the Performance of Blocking Agents on Gold Polystyrene Surfaces. Langmuir 24.

[32] Jeyachandran, Y.L. 2010 Efficiency of Blocking of Non-specific Interaction of Different Proteins by BSA Adsorbed on Hydrophobic and Hydrophilic Surfaces. Journal of Colloid and Interface Science 341, 136-142.

[33] Rankl, M. 2006 Conformational Reorientation of Immunoglobulin G During Nonspecific Interaction with Surfaces. Chemphyschem 7, 837-846.

[34] Steinitz, M. 2000 Quantitation of the Blocking Effect of Tween 20 and Bovine Serum Albumin in ELISA Microwells. Analytical Biochemistry 282, 232-238.

[35] Haab, B.B. 2000 Protein Microarrays for Highly Parallel Detection and Quantitation of Specific Proteins and Antibodies in Complex Solutions. GenomeBiology.com 1.

[36] Greenwood, F.C. 1963 The Preparation of I-131-Labelled Human Growth Hormone of High Specific Radioactivity. Biochemical Journal 89, 114-123.

[37] Das, J. 2011 Protein Detection Using Arrayed Microsensor Chips: Tuning Sensor Footprint to Achieve Ultrasensitive Readout of CA-125 in Serum and Whole Blood. Analytical Chemistry (Washington) 83, 1167-1172.

[38] Yadav, S., Carrascosa, L.G., Sina, A.A.I., Shiddiky, M.J.A., Hill, M.M. \& Trau, M. 2016 Electrochemical Detection of Protein Glycosylation Using Lectin and Protein-Gold Affinity Interactions. Analyst 141, 2356-2361. (doi:10.1039/C6AN00528D).

[39] Brown, A.P. 1977 Cyclic and Differential Pulse Voltammetric Behavior of Reactants Confined to the Electrode Surface. Analytical Chemistry (Washington) 49, 1589-1595.

[40] Kung, K.H. 1988 Electron Transfer Processes Between Hydroquinone and Iron Oxides. Clays and Clay Minerals 36, 303-309.

[41] Chithrani, B.D. 2007 Elucidating the Mechanism of Cellular Uptake and Removal of Protein-Coated Gold Nanoparticles of Different Sizes and Shapes. Nano Letters 7, 1542-1550. 
[42] Patel, P.C., Giljohann, D.A., Daniel, W.L., Zheng, D., Prigodich, A.E. \& Mirkin, C.A. 2010 Scavenger Receptors Mediate Cellular Uptake of Polyvalent Oligonucleotide-Functionalized Gold Nanoparticles. Bioconjugate Chemistry 21, 2250-2256.

[43] Shrivastava. 2011 Methods for the Determination of Limit of Detection and Limit of Quantitation of the Analytical Methods. Chronicles of Young Scientists $\mathbf{2}$.

[44] Yan, M. 2013 An Aptasensor for Sensitive Detection of Human Breast Cancer Cells by Using Porous GO/Au Composites and Porous PtFe Alloy as Effective Sensing Platform and Signal Amplification Labels. Analytica Chimica Acta 798, 33-39.

[45] Zhu, X. 2013 Sensitive Detection of Human Breast Cancer Cells Based on Aptamer-Cell-Aptamer Sandwich Architecture. Analytica Chimica Acta 764, 59-63.

[46] Li, T. 2010 Detection of Breast Cancer Cells Specially and Accurately by an Electrochemical Method. Biosensors \& Bioelectronics 25, 2686-2689.

[47] Arya, S.K. 2013 Anti-EpCAM Modified LC-SPDP Monolayer on Gold Microelectrode Based Electrochemical Biosensor for MCF-7 cells detection. Biosensors \& Bioelectronics 41, 446-451.

[48] Seven, B. 2013 Impedimetric Biosensor for Cancer Cell Detection. Electrochemistry Communications 37, 36-39.

[49] Liu, F. 2014 Application of ZnO/Graphene and S6 Aptamers for Sensitive Photoelectrochemical Detection of SK-BR-3 Breast Cancer Cells Based on a Disposable Indium Tin Oxide Device. Biosensors \& Bioelectronics 51, 413-420.

[50] Salahandish, R. 2018 Nano-biosensor for Highly Sensitive Detection of HER2 Positive Breast Cancer. Biosensors \& Bioelectronics 117, 104-111.

[51] Zhu, Y. 2013 Ultrasensitive and Selective Electrochemical Diagnosis of Breast Cancer Based on a Hydrazine-Au Nanoparticle-Aptamer Bioconjugate. Analytical Chemistry (Washington) 85, 10581064.

[52] Jiang, G. 2017 Colorimetric and Visual Determination of Adenosine Triphosphate Using a Boronic acid as the Recognition Element, and Based on the Deaggregation of Gold nanoparticles. Mikrochimica Acta (1966) 184, 4305-4312.

[53] Cahall, C.F. 2015 A Quantitative Perspective on Surface Marker Selection for the Isolation of Functional Tumor Cells. Breast Cancer :Basic and Clinical Research 9s1. 
Table 1. Cell capture platform performance

\begin{tabular}{|c|c|c|c|}
\hline Method & $\begin{array}{l}\text { Biorecognition } \\
\text { platform }\end{array}$ & Cell capture & $\begin{array}{l}\text { Net amperometry } \\
\text { response / } \mu \mathrm{A}\end{array}$ \\
\hline Scheme 3 (1) & $\begin{array}{l}\text { STE/Bio.Anti- } \\
\text { HER2 }\end{array}$ & 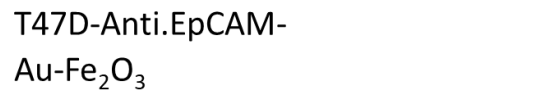 & $\sim 100$ \\
\hline Scheme 3 (2) & $\begin{array}{l}\text { STE/Bio.Anti- } \\
\text { EGFR }\end{array}$ & $\begin{array}{l}\text { T47D-Bio.Anti-EpCAM- } \\
\text { STE.MBs }\end{array}$ & $\sim 40$ \\
\hline Scheme 3 (3) & $\begin{array}{l}\text { STE/Bio.Anti- } \\
\text { EGFR }\end{array}$ & $\begin{array}{l}\text { STE.MBs-Bio.Anti- } \\
\text { EpCAM/T47D/Anti.EpCAM-Au-Fe } \mathrm{O}_{3}\end{array}$ & $3_{3}$ \\
\hline $\begin{array}{l}\text { Direct cell capture } \\
\text { with STE }\end{array}$ & STE/Bio.Anti-EpCAM & T47D & $\sim 5$ \\
\hline
\end{tabular}

STE, streptavidin modified screen printed electrode. Bio. (Biotinylated).

Table 2. Limit of detection of the existing biosensor platforms

\begin{tabular}{|c|c|c|c|c|}
\hline$\frac{\text { Breast cancer }}{\text { type/target }}$ & Biosensor specifications & $\begin{array}{l}\text { Linear range (cells } \\
\mathrm{mL}^{-1} \text { ) }\end{array}$ & $\begin{array}{l}\text { Detection limit } \\
\left(\text { cells } \mathrm{mL}^{-1} \text { ), LOD }\right.\end{array}$ & Reference \\
\hline $\begin{array}{l}\text { MCF-7 } \\
\text { (MUC1) }\end{array}$ & $\begin{array}{l}\text { Porous GO/Au composites and } \\
\text { PtFe alloy }\end{array}$ & $10^{2}-5 \times 10^{7}$ & 38 & [44] \\
\hline $\begin{array}{l}\text { MCF-7 } \\
\text { (MUC1) }\end{array}$ & $\begin{array}{l}\text { HRP/MUC1/aptamer1/Au } \\
\text { electrode }\end{array}$ & $10^{2}-1 \times 10^{7}$ & 100 & [45] \\
\hline $\begin{array}{l}\text { MCF-7 } \\
\text { (MUC1 \& CEA) }\end{array}$ & $\begin{array}{l}\text { MUC1/aptamer/MCF-7/anti-CEA- } \\
\text { CdS NPs }\end{array}$ & $10^{4}-10^{7}$ & $3.3 \times 10^{2}$ & [46] \\
\hline $\begin{array}{l}\text { MCF-7 } \\
\text { (EPCAM) }\end{array}$ & $\begin{array}{l}\text { Anti-EpCAM/LC-SPDP/Au } \\
\text { electrode }\end{array}$ & $10^{5}-10^{7}$ & $10^{5}$ & [47] \\
\hline $\begin{array}{l}\text { MCF-7 } \\
\text { (HER-2) }\end{array}$ & $\begin{array}{l}\text { Anti-cerbB2/polypyrrole- } \\
\text { NHS/GCE }\end{array}$ & $10^{2}-10^{4}$ & 100 & [48] \\
\hline $\begin{array}{l}\text { SK-BR-3 } \\
\text { (HER-2) }\end{array}$ & $\begin{array}{l}\text { S6 aptamer/AuNPs/ZnO/G/ITO } \\
\text { electrode }\end{array}$ & $10^{2}-10^{6}$ & 58 & [49] \\
\hline $\begin{array}{l}\text { SK-BR-3 } \\
\text { (HER-2) }\end{array}$ & NFG/AgNPs/PANI & $10-5 \times 10^{6}$ & 2 & [50] \\
\hline $\begin{array}{l}\text { SK-BR-3 } \\
\text { (HER-2) }\end{array}$ & Hydrazine/AuNPs/aptamer & $50-2 \times 10^{4}$ & 26 & [51] \\
\hline $\begin{array}{l}\text { MBA-MB-231 \& } \\
\text { T47D } \\
\left(\mathrm{H}_{2} \mathrm{O}_{2} \text { traces in }\right. \\
\text { cells })\end{array}$ & AuPtPd/rGO-modified GCE & $0.005 \mu \mathrm{M}-6.5 \mathrm{mM}$ & $2 \mathrm{nM}$ & [52] \\
\hline $\begin{array}{l}\text { T47D } \\
\text { (EPCAM \& HER-2) }\end{array}$ & $\begin{array}{l}\text { Anti-EpCAM/Au- } \mathrm{Fe}_{2} \mathrm{O}_{3} / \text { Bio.Anti- } \\
\text { HER-2/STE }\end{array}$ & $10-10^{5}$ & $\begin{array}{c}0.4 \cup \mathrm{mL}^{-1}(\mathrm{LOD}) \\
\mathrm{LOQ}, 4 \cup \mathrm{mL}^{-1} \\
(\mathrm{LOQ})\end{array}$ & This work* \\
\hline
\end{tabular}

*LOD, is the lowest concentration of the analyte detected in the sample but not quantitated under the stated condition of the test. LOQ, is the lowest concentration of the analyte determined with acceptable precision and accuracy under the stated conditions of test. 
Scheme 1. Classification of breast cancer biomarkers and assay profiling. T47D cell line is from the human breast cancer cells, and OVCAR 3 cell line is from the human ovarian cancer cells. The scheme shows the basic concept for the classification of biomarkers discussed in this paper. EpCAM (Epithelial Cell Adhesion Molecule), EGFR (Epithelial Growth Factor Receptor). HER-2(Human Epidermal Growth Factor Receptor 2).PD-L1 (Programmed Death-Ligand 1). PD-1(Programmed Cell Death Protein 1). CA-125 (Cancer Antigen, 125). ER (Oestrogen Receptor). PR (Progesterone Receptor).
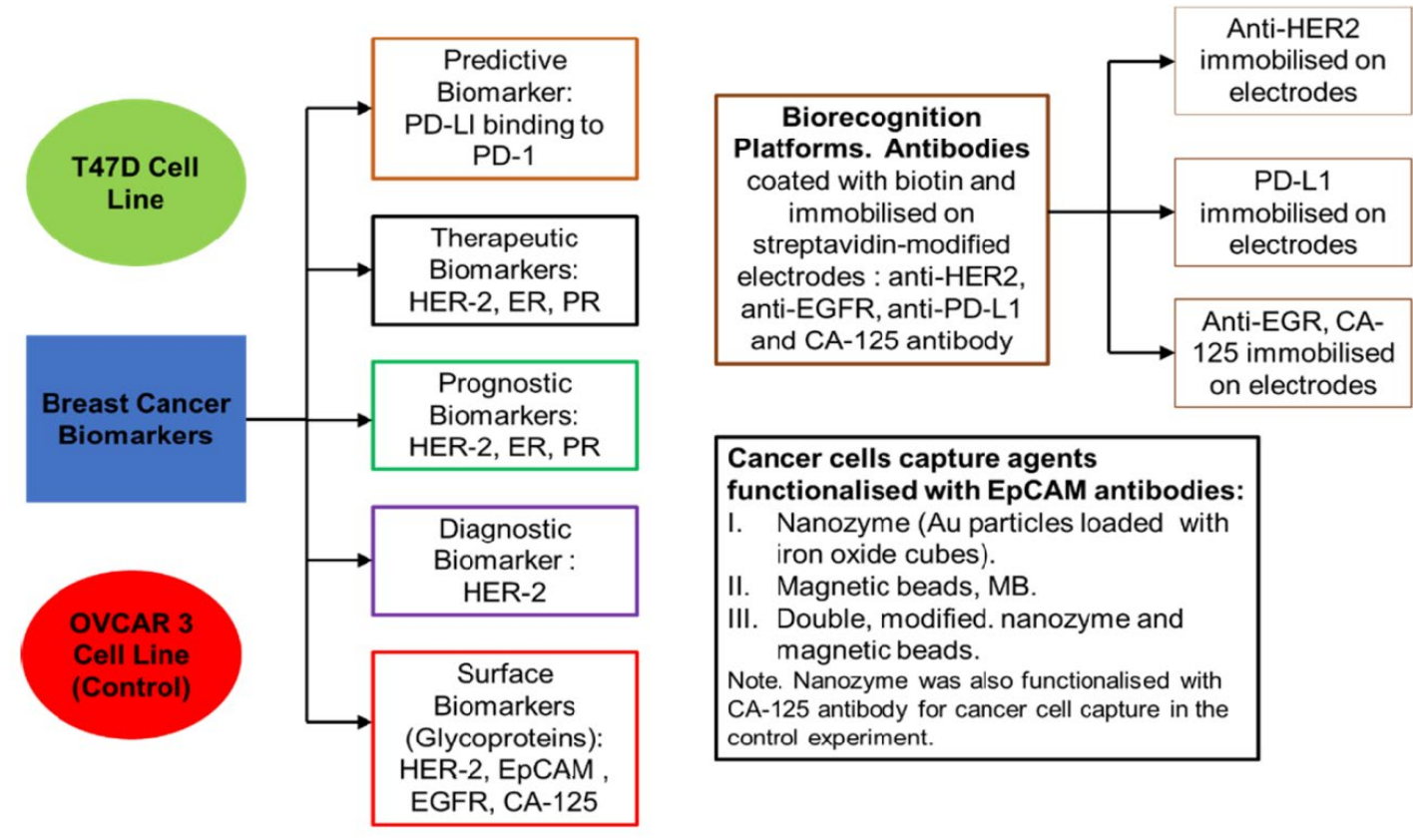

Cancer cells capture agents

functionalised with EpCAM antibodies:

I. Nanozyme (Au particles loaded with iron oxide cubes).

II. Magnetic beads, MB.

III. Double, modified. nanozyme and magnetic beads.

Note. Nanozyme was also functionalised with CA-125 antibody for cancer cell capture in the control experiment.

Scheme 2. The stages in the electrochemical detection of cancer cells (1) Nanozyme functionalised with the EpCAM antibody (capture agent) (2) Dispersed the capture agent in cancer cells containing PBS buffer solution at pH 7.4. We extracted the cancer cells with an external magnet (3) Biosensing platform developed. (4) Transferred the cancer cells captured on the recognition platform (5) Electrochemical detection and profiling of cancer cells using the amperometry method. 


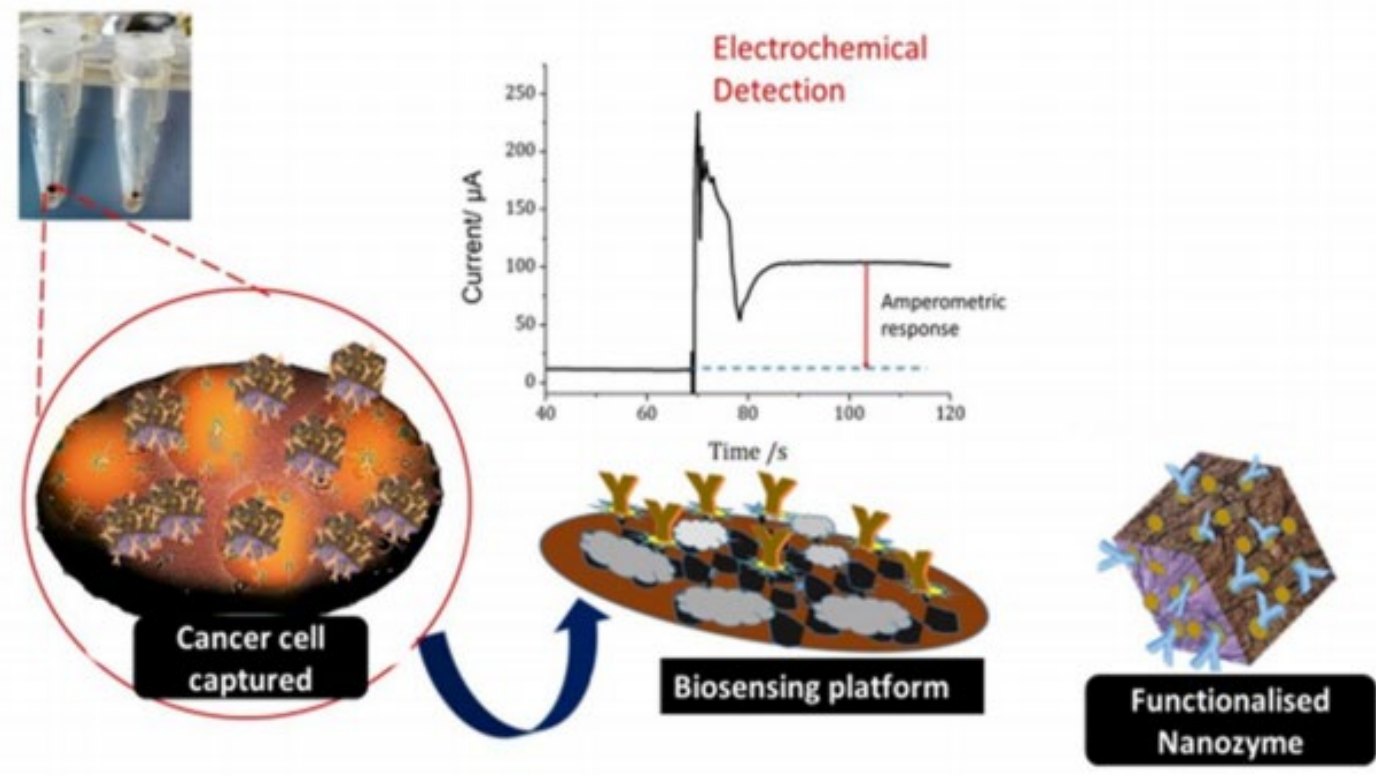

Scheme 3. Pathways to assay schemes. Scheme 3(1) biotinylated anti-HER2/streptavidin-modified electrode. Scheme 3 (2) and Scheme 3 (3) biotinylated anti-EGFR/streptavidin-modified electrode.

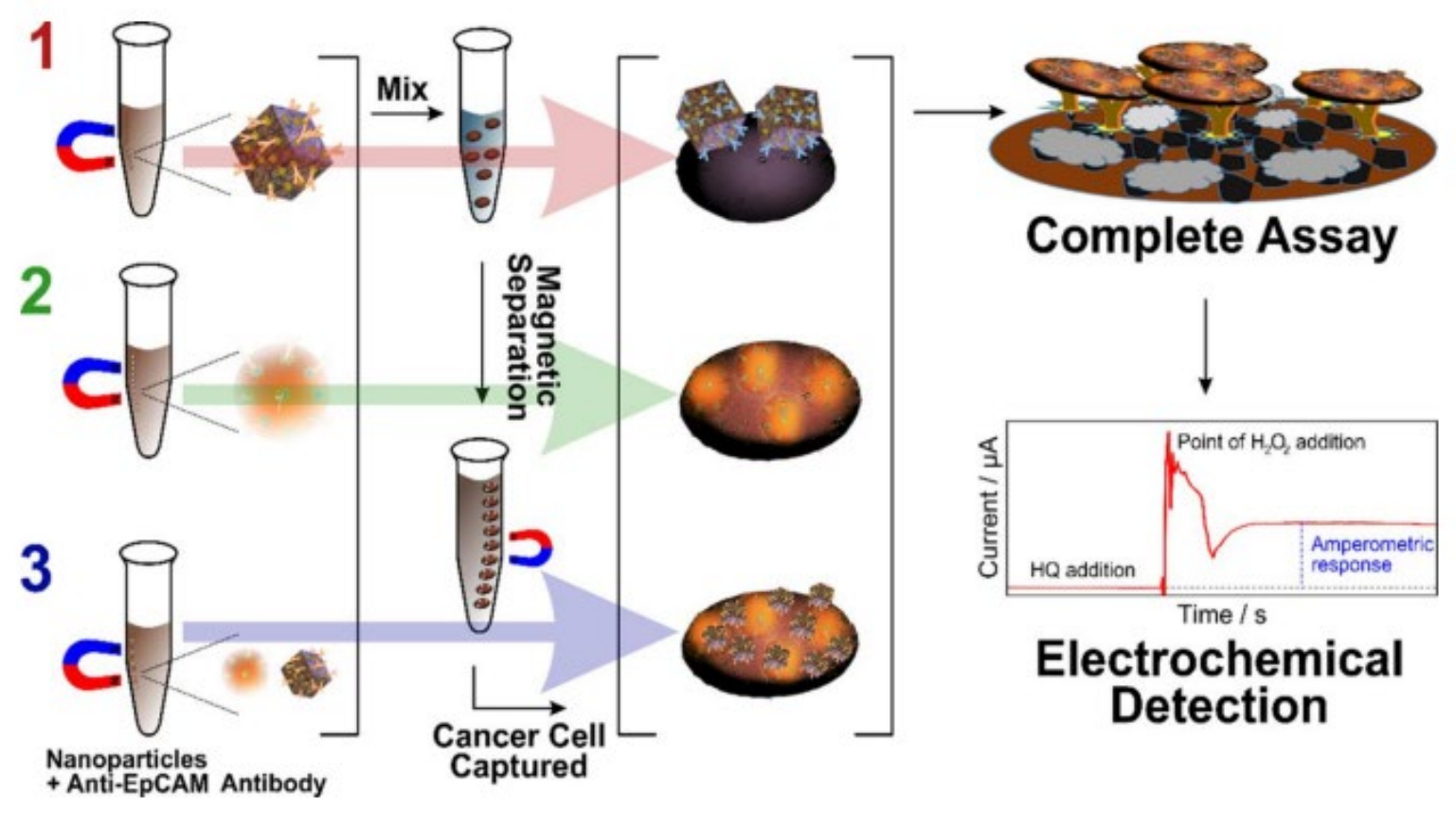


Figure 1. The biosensing performance of the platform was characterised electrochemically with DPV. The biosensing part, biotinylated anti-HER2 and streptavidin-modified electrodes. Figure 1(a) BSA \% at different concentrations (b) linear range of BSA concentration. The DPV experiment monitored in $2.5 \mathrm{mM}\left[\mathrm{K}_{3} \mathrm{Fe}(\mathrm{CN})_{6}\right]$ and $2.5 \mathrm{mM}\left[\mathrm{K}_{4} \mathrm{Fe}(\mathrm{CN})_{6}\right]$ electrolyte solution.
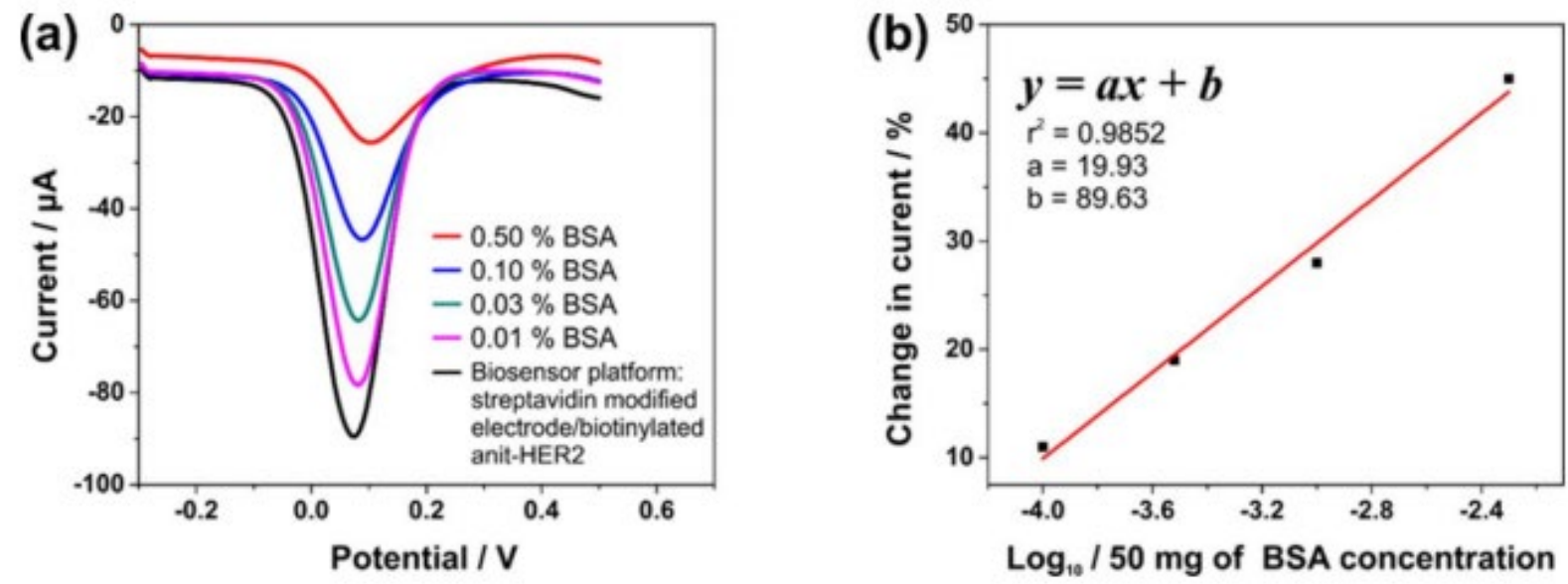

Figure 2. The DPV method was used to monitor the different stages of assay development. The streptavidin-modified electrode conjugated to biotinylated HER-2 antibody, with the subsequent addition of $0.1 \%$ BSA concentration for 10 min. Finally, the cells captured (anti-EpCAM/Au- $-\mathrm{Fe}_{2} \mathrm{O}_{3}$ dispersed in PBS buffer containing T47D cells). The DPV experiment monitored in $2.5 \mathrm{mM}\left[\mathrm{K}_{3} \mathrm{Fe}\right.$ (CN) 6] and $2.5 \mathrm{mM}\left[\mathrm{K}_{4} \mathrm{Fe}(\mathrm{CN})_{6}\right]$ electrolyte solution.

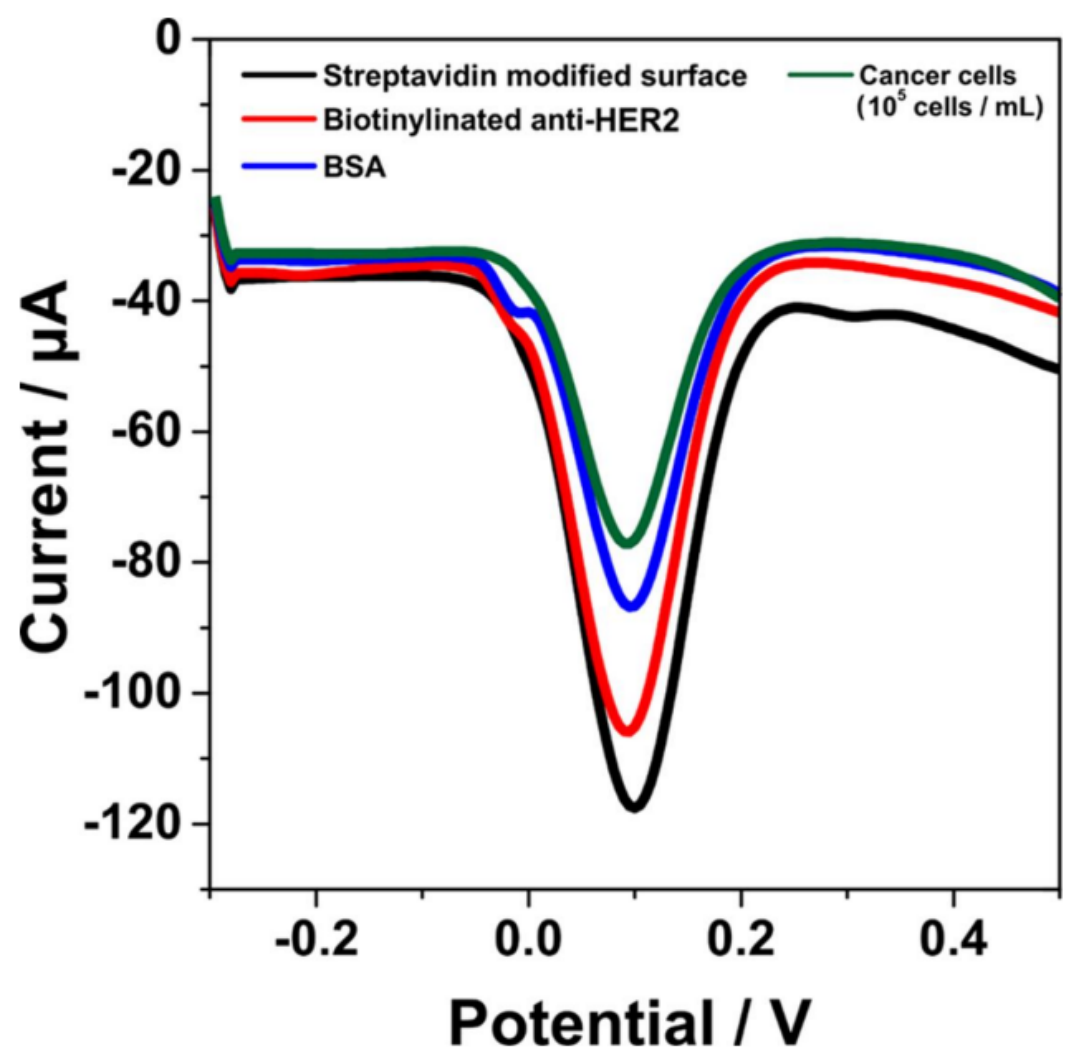


Figure 3. Amperometry (current versus time plot) response in the presence of cancer cells using $1 \mathrm{mM}$ $\mathrm{HQ} / 10 \mathrm{M} \mathrm{H}_{2} \mathrm{O}_{2}$.

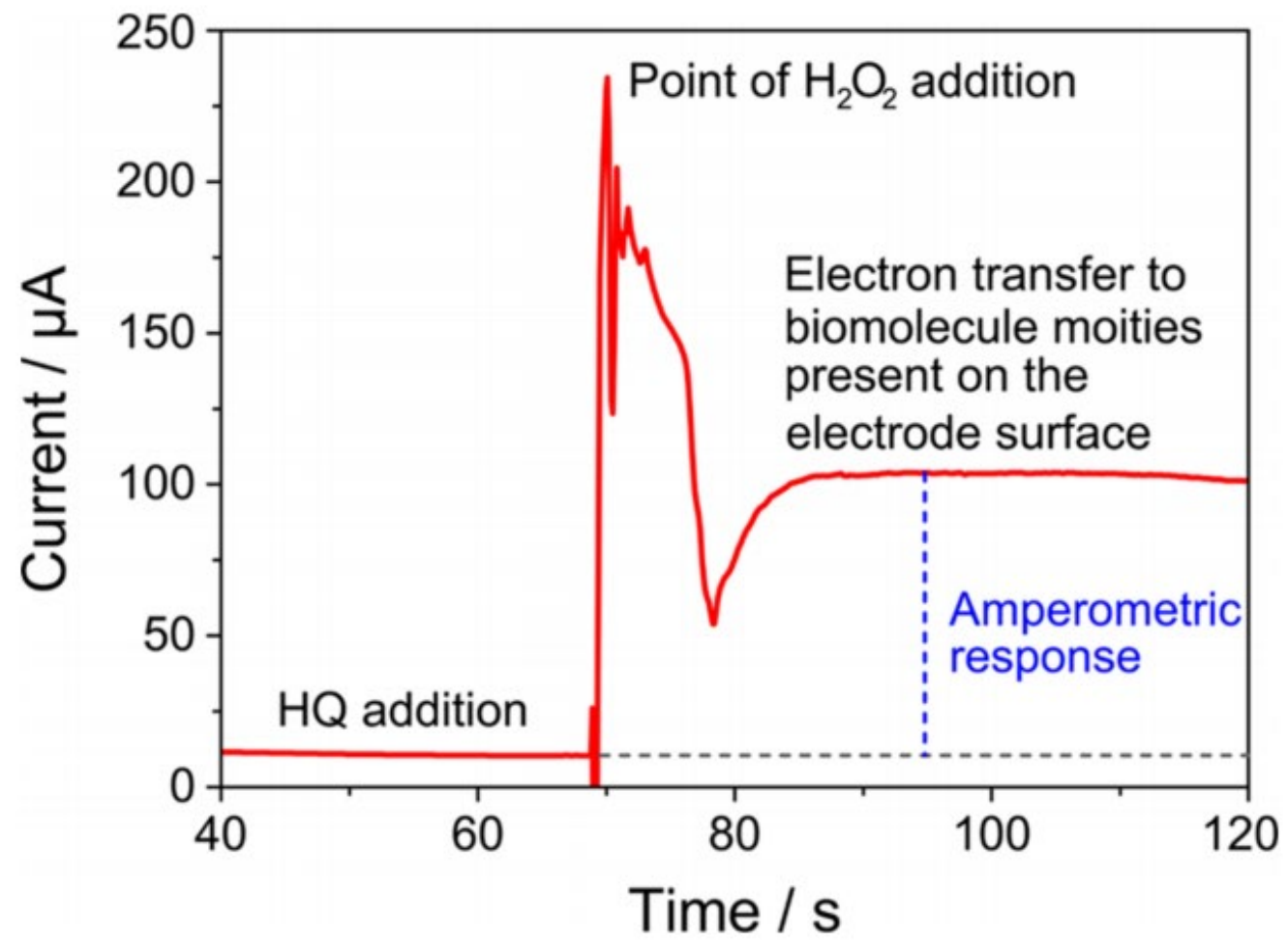

Figure 4. Assay performances in the presence of $1 \mathrm{mM} \mathrm{HQ} / 10 \mathrm{M} \mathrm{H}_{2} \mathrm{O}_{2}$. The biosensing interfaces, biotinylated anti-HER-2 as Scheme 3(1). Schemes 3(2) and 3(3) as biotinylated anti-EGFR. Biotinylated anti-EpCAM used in direct cell capture. Relative standard deviation (RSD) of $5.0 \%(n=3) *$ Net response was unobtainable in Scheme 3(2) due to no current difference in with/without cells.

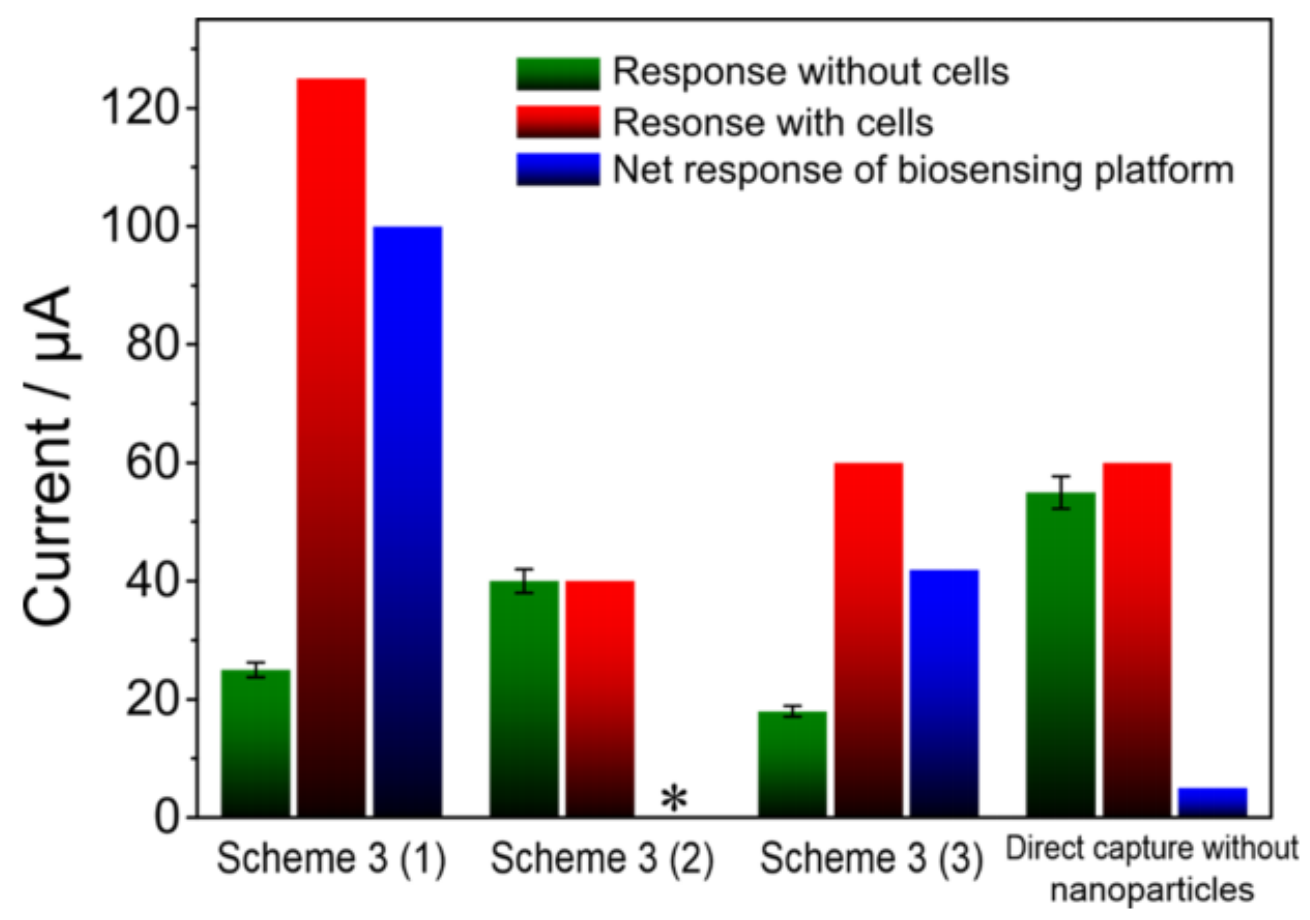


Figure 5. The capture efficiency of cancer cells and the expansion of cancer cells released (a) The capture efficiency was enumerated directly using an automated cell counter (b) numbered 1 to 5 , the photomicrographs of T47D breast cancer cells captured at different serial dilution concentrations (10 to $10^{5}$ cells $/ \mathrm{mL}$ (scale bar $=500 \mu \mathrm{m}$ ). Numbered 6 , digital images of viable cells captured (green colour dots as viable cells and red color dots as dead cells) (c) Post capture expansion of T47D cancer cells in a standard tissue flask (scale bar $=100 \mu \mathrm{m}$ ).
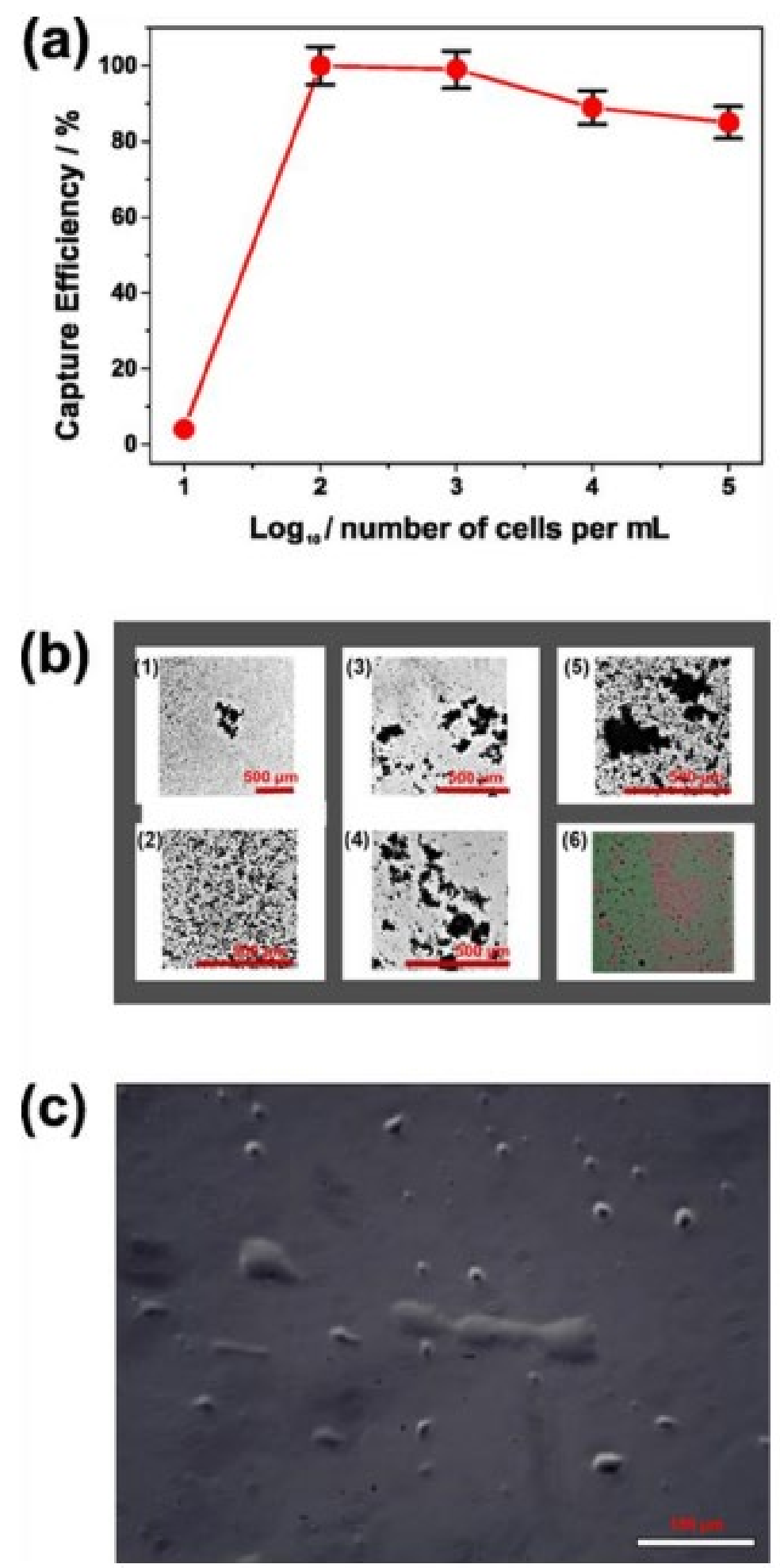
Figure 6. (a) The direct amperometry responses (current versus time) obtained for breast cancer cells captured at different serial dilution concentrations (10 to $10^{5}$ cells $/ \mathrm{mL}$ ). The responses measured in $1 \mathrm{mM} \mathrm{HQ} / 10 \mathrm{M} \mathrm{H}_{2} \mathrm{O}_{2}$. Relative standard deviation (RSD) of $5.0 \%(n=3)$. The calibration plot in Figure $6 \mathrm{~b}$ was used to calculate LOD and LOQ values. The slope of the graph, 5.4, and the standard error of slope, 0.7 . The linear regression $\left(R^{2}\right), 0.93$. We considered the net responses in the LOD and LOQ calculations.
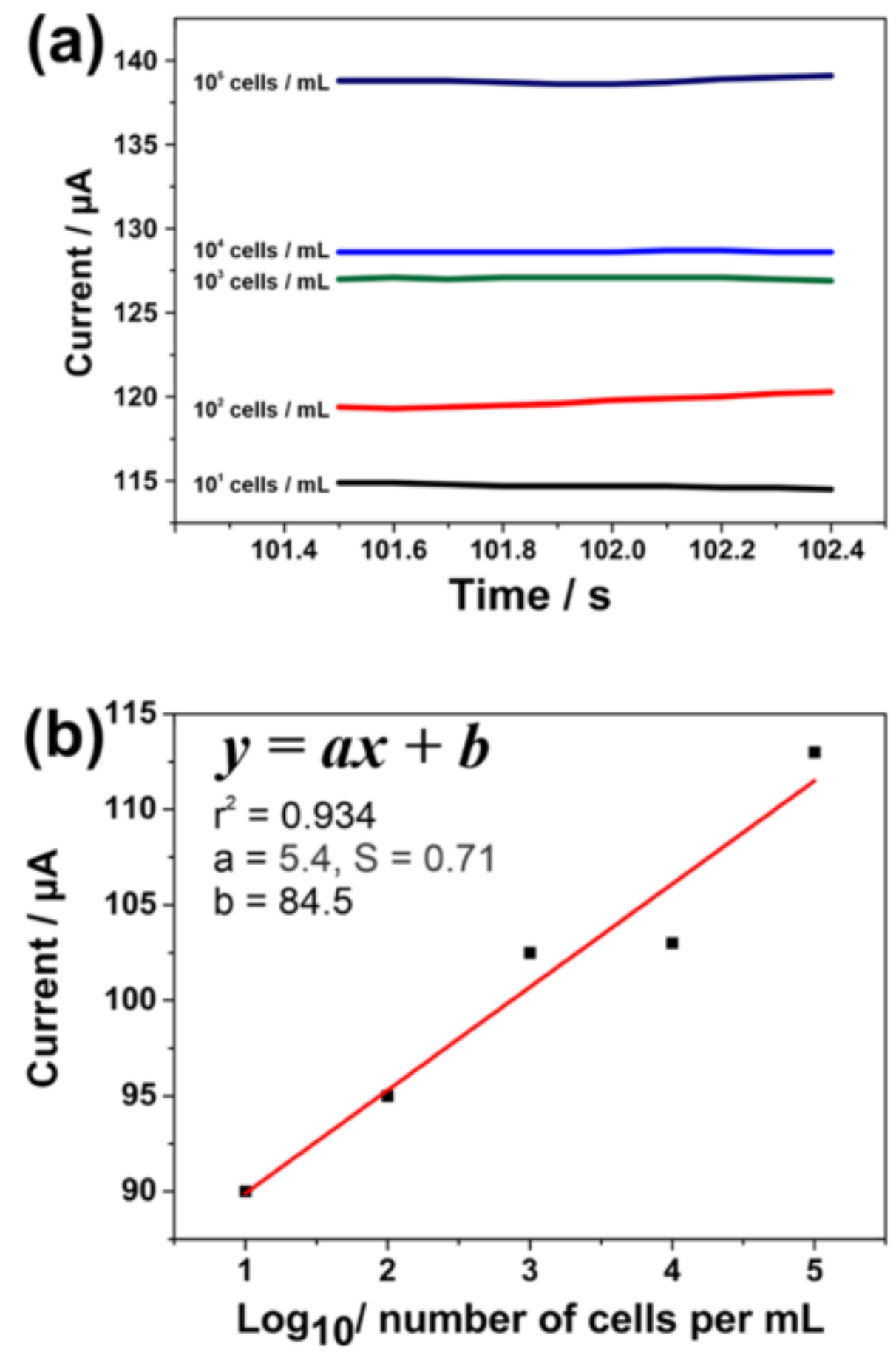
Figure 7. The direct amperometry responses of current for (a) I. Positive experiment and II-V negative controls. (b) Direct amperometry (i-t) profile of the negative controls. The responses measured in the presence of $1 \mathrm{mM} \mathrm{HQ} / 10 \mathrm{M} \mathrm{H}_{2} \mathrm{O}_{2}$. Sensing platforms, biotinylated: anti-HER and CA-125 antibody. CA 125 is a cancer antigen marker for ovarian cancer cells. Relative standard deviation (RSD) of $5.0 \%$ $(n=3)$.
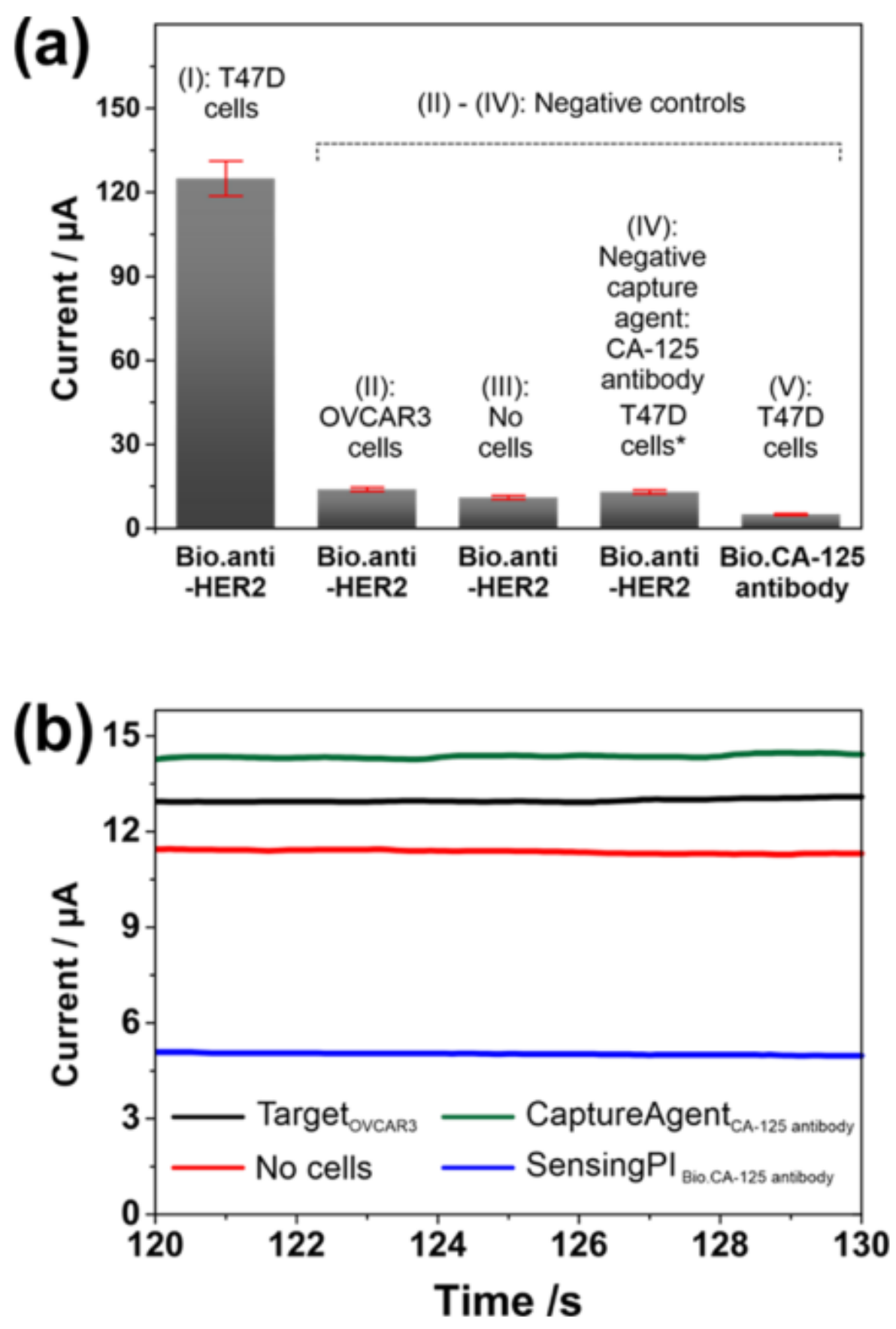
Figure 8. Amperometry responses from the biomarker expressions in the presence of $1 \mathrm{mM} \mathrm{HQ} / 10$ $\mathrm{M} \mathrm{H}_{2} \mathrm{O}_{2}$, with T47D cancer breast cancer cells. Relative standard deviation (RSD) of $5.0 \%(n=3)$.

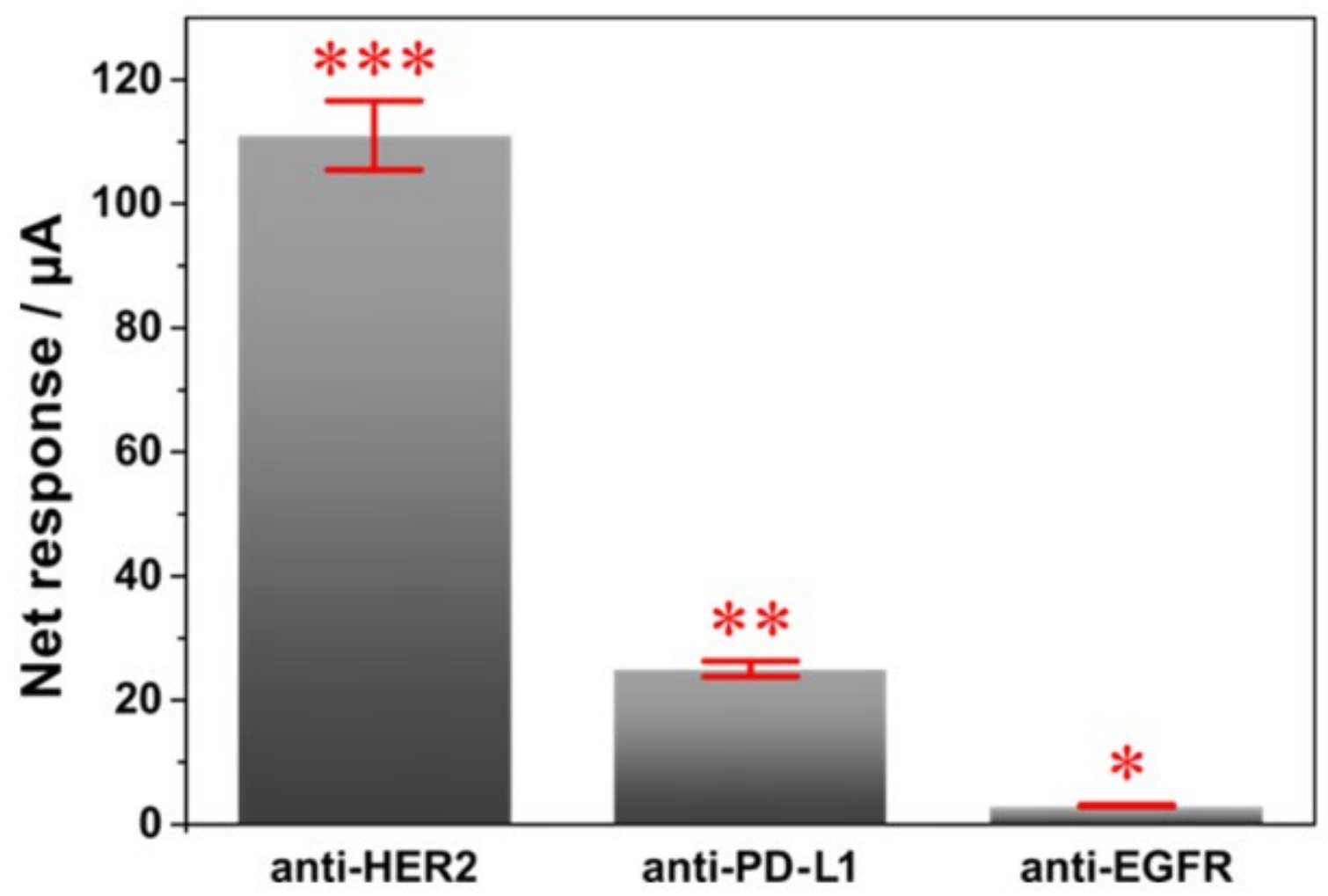




\section{Supplementary information}

Scheme S1. Cancer cells captured with nanozyme. The biosensing platform: biotinylated antiHER2 integrated on the streptavidin electrode surface.

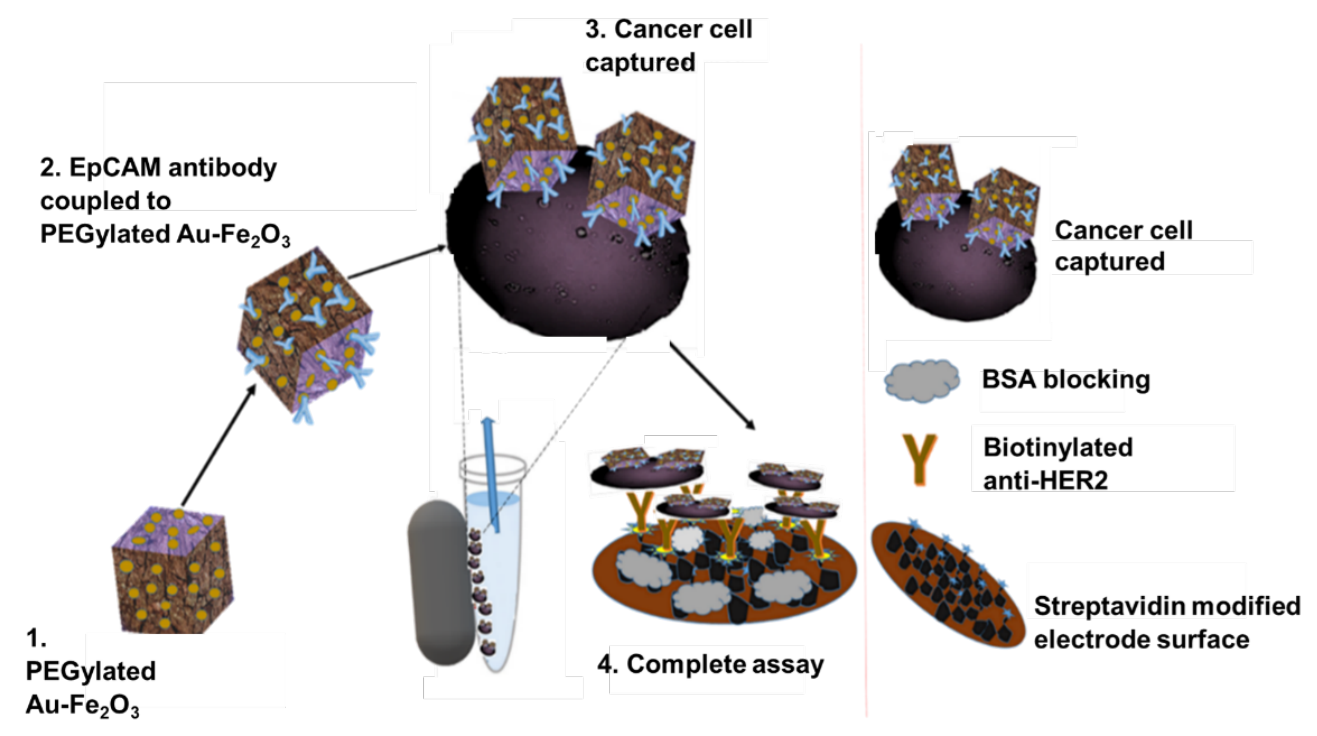

Scheme S2. Cancer cells captured with magnetic beads, MBs. The biosensing platform: biotinylated anti-EGFR integrated on the streptavidin electrode surface.

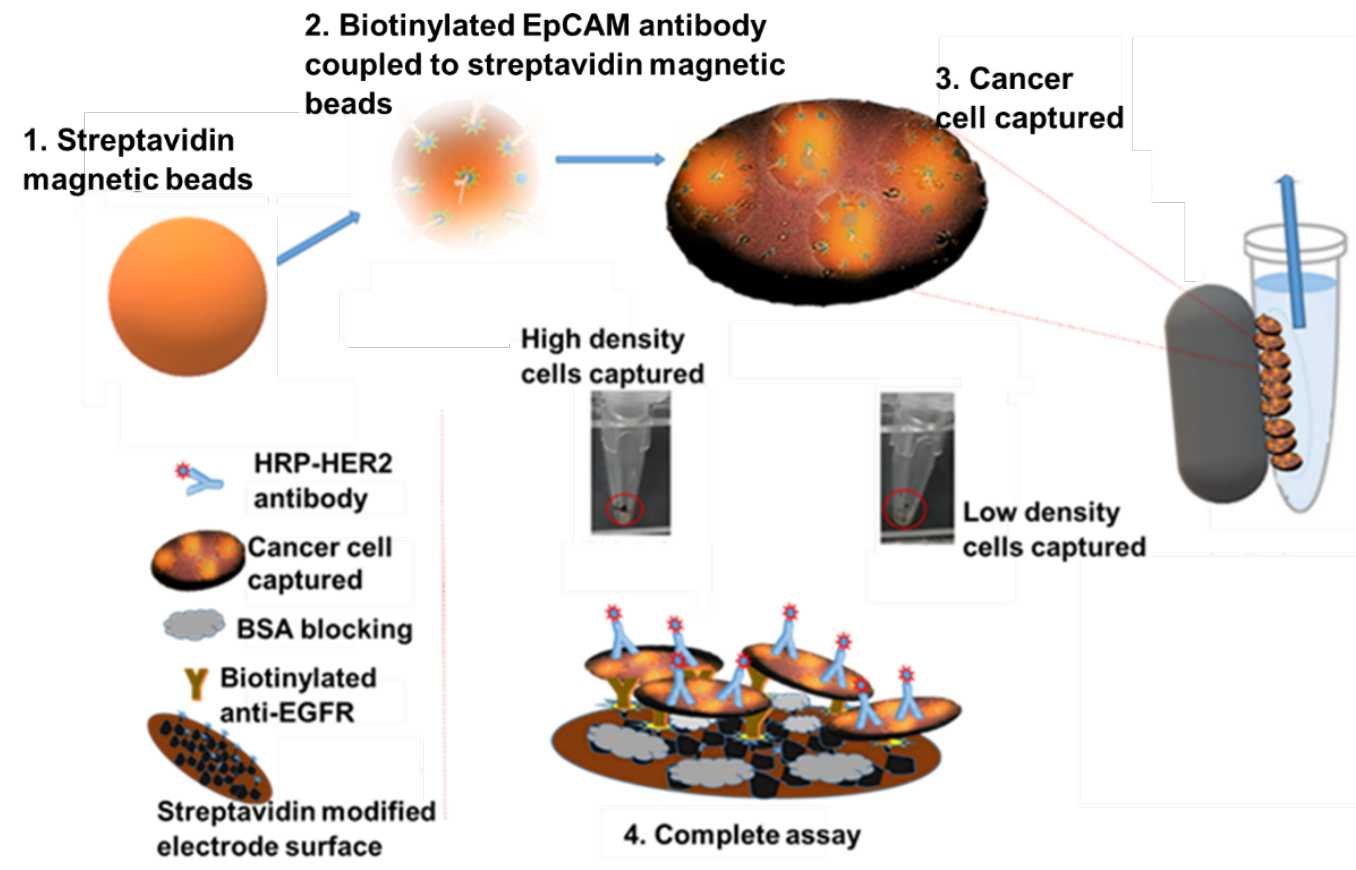

Scheme S3. Cancer cells captured with double-modified nanomaterials, MBs and nanozyme. The biosensing platform: biotinylated anti-EGFR integrated on the streptavidin electrode surface. 


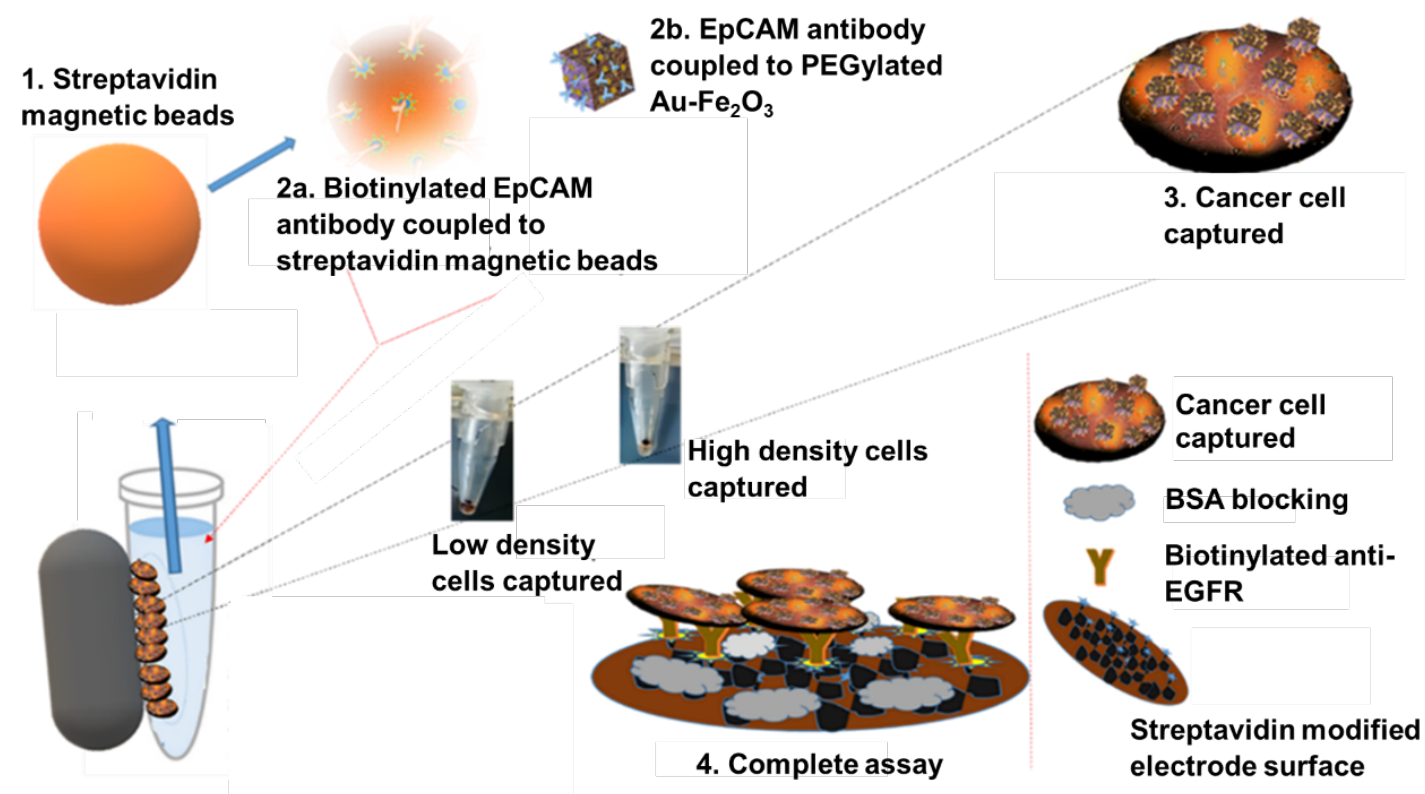

Scheme S4. Direct cancer cells capture. Cancer cells captured directly with anti-EpCAM. HRPanti-HER2 was used to enhance the signal response. The biosensing platform: biotinylated anti-EpCAM integrated on the streptavidin electrode surface.

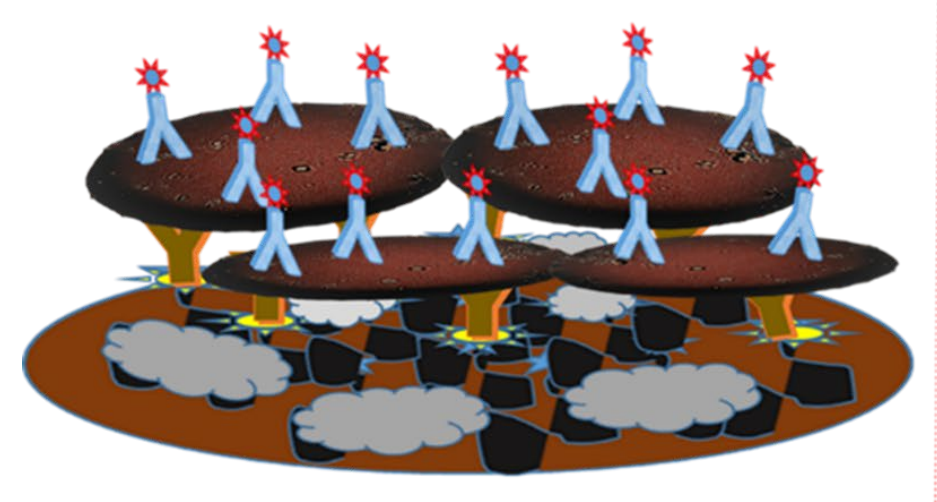

5.

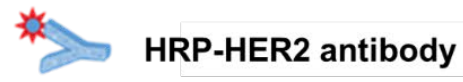

4.

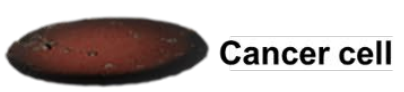

3.

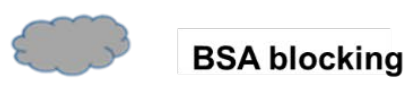

2.

Biotinylated

EpCAM antibody

1.

Streptavidin modified electrode surface

Schemes. Schematic representation of the different assays developed. No scale considerations (not drawn to scale) in all the schemes and to the number of cancer cells present on the electrode surface. 

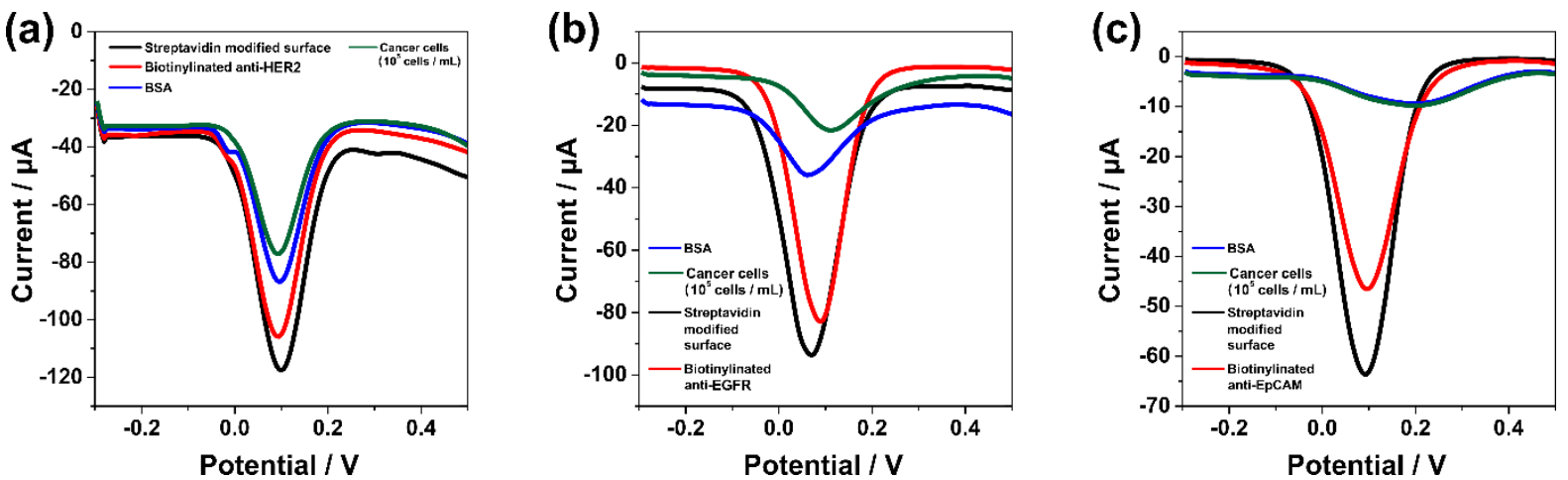

Figure S1. DPV method was used to monitor the fabrication of platforms during the different stages of assay development. Streptavidin-modified electrode was conjugated to biotinylated: (a) anti-HER (b) EGFR and (c) EpCAM. BSA was added for $10 \mathrm{~min}$. Finally, in a and b cancer cells captured (T47D cancer cells) were added, except for (c) that cells were incubated directly onto the modified electrode surface. The DPV experiment was monitored in PBS solution containing $2.5 \mathrm{mM}\left[\mathrm{K}_{3} \mathrm{Fe}(\mathrm{CN})_{6}\right]$ and $2.5 \mathrm{mM}\left[\mathrm{K}_{4} \mathrm{Fe}(\mathrm{CN})_{6}\right]$.

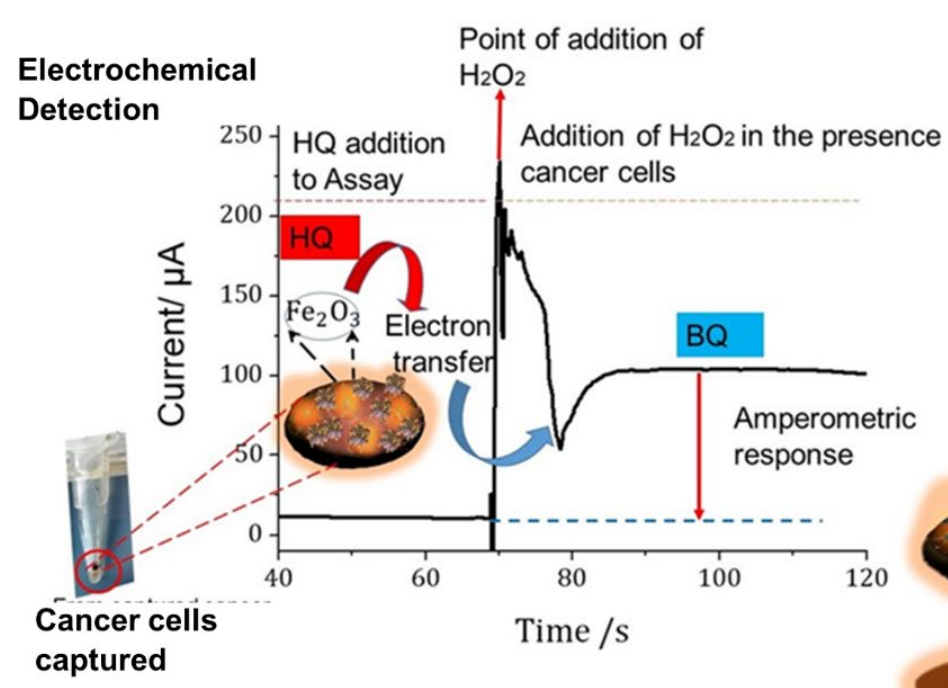

\section{Functionalised Nanozyme}

Biorecognition platforms investigated/streptavidin modified electrode coupled to biotinylated : 1 . HER2 antibody 2. EGFR antibody 3. EpCAM antibody 4. PD-L1 antibody 5. CA-125 antibody

Complete Assay

Figure S2. Amperometry responses were measured in the absence and presence of cancer cells using $1 \mathrm{mM} \mathrm{HQ} / 10 \mathrm{M} \mathrm{H}_{2} \mathrm{O}_{2}$. The following biomarkers investigated along with their corresponding antibodies: EpCAM (Epithelial Cell Adhesion Molecule), EGFR (Epithelial Growth Factor Receptor). HER-2(Human Epidermal Growth Factor Receptor 2).PD-L1 (Programmed Death-Ligand 1). PD-1(Programmed Cell Death Protein 1). CA-125 (Cancer Antigen, 125). In principle, oxides with a higher surface area such as nanozyme will produce as much $\mathrm{Q}$ from $\mathrm{HQ}$. The $\mathrm{pH}$ has no influence on the oxidation of hydroquinone in the presence of an iron oxide loaded surface material. We observed a rapid conversion of hydroquinone ( $\mathrm{HQ}$ ) to benzoquinone $(\mathrm{Q})$ as the concentration of $\mathrm{HQ}$ decreased in the presence of $\mathrm{Au}_{2}-\mathrm{Fe}_{2} \mathrm{O}_{3}$. 

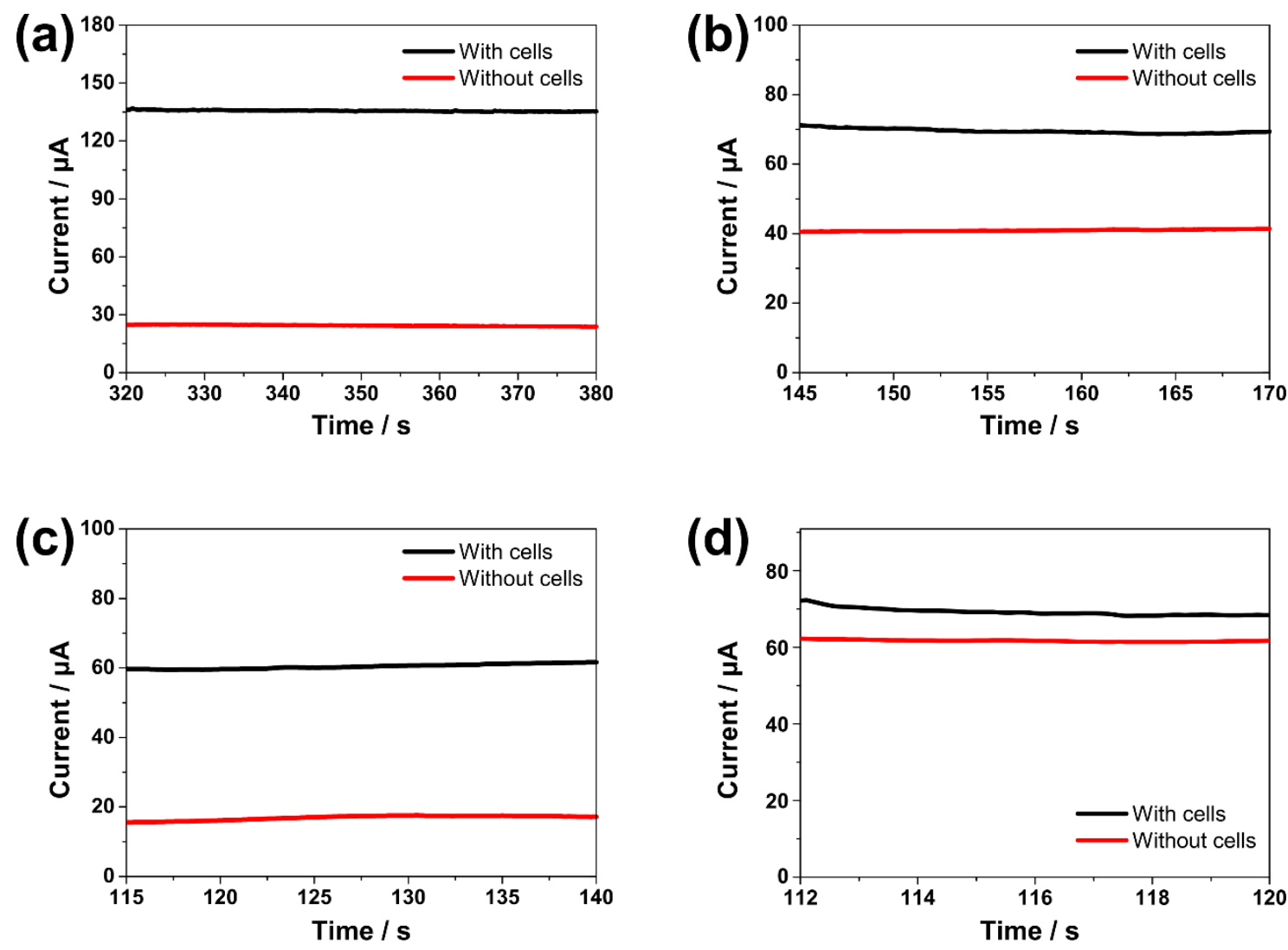

Figure S3. Stabilised amperometry lines in the absence and presence of cancer cells for Schemes 1 to 4 using $1 \mathrm{mM} \mathrm{HQ} / 10 \mathrm{M} \mathrm{H}_{2} \mathrm{O}_{2}$. Biotinylated: (a) anti-HER2 (b), (c) anti-EGFR and (d) anti-EpCAM integrated on streptavidin electrode interface. Concentration of cells, $10^{5}$ cells/ $\mathrm{mL}$. The cells were incubated directly on the biorecognition platforms. The unattached cells washed with PBS. We calculated the net amperometry for each response using, Amperometry response, $A m p_{(R)}=I_{R}\left(H Q / H_{2} \mathrm{O}_{2}\right.$ stabilised response) $-I_{R}$ ( $H Q$ addition). The line response for $\mathrm{HQ}$ addition is shown in Figure $\mathrm{S2}$. 


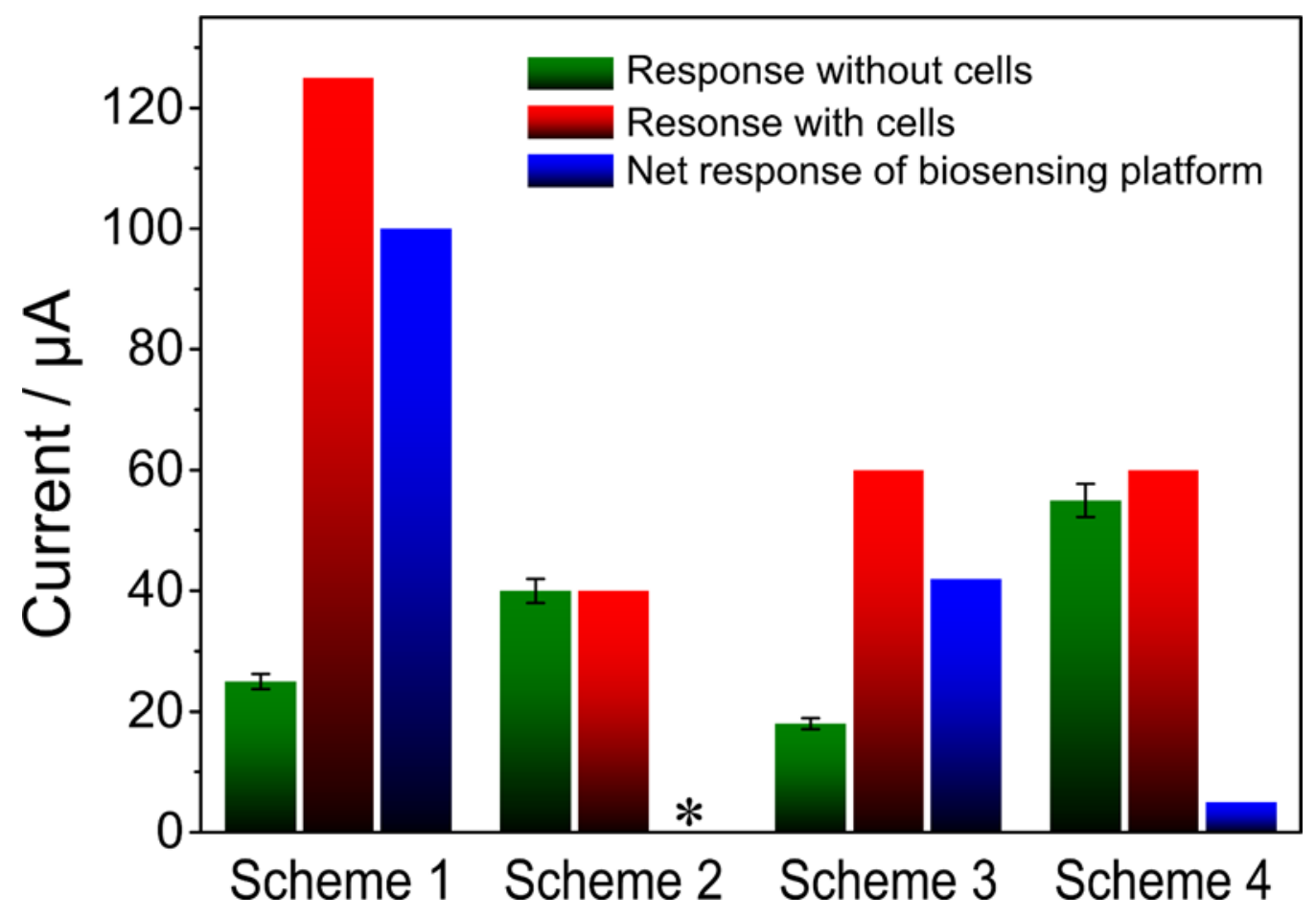

Figure S4. Assay performances in the presence of $1 \mathrm{mM} \mathrm{HQ} / 10 \mathrm{M} \mathrm{H}_{2} \mathrm{O}_{2}$. Sensing platforms include biotinylated: anti-HER2 (Scheme 1) anti-EGFR (Schemes 2 and 3) and anti-EpCAM (Scheme 4) integrated on streptavidin electrode surface. Relative standard deviation (RSD) of $5.0 \%(n=3) .{ }^{*}$ Net response was unobtainable due to no current difference in with/without cells for scheme 2 .

Acknowledgements: V.A thanks Griffith University for the GUPR and GUIPR scholarships.

Data accessibility. The authors confirm that the data supporting the findings of this study are available within the results section of this paper.

Competing interests. We have no competing interest. 